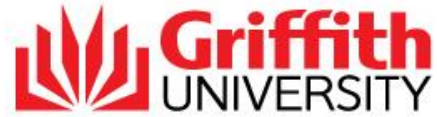

Griffith Business School

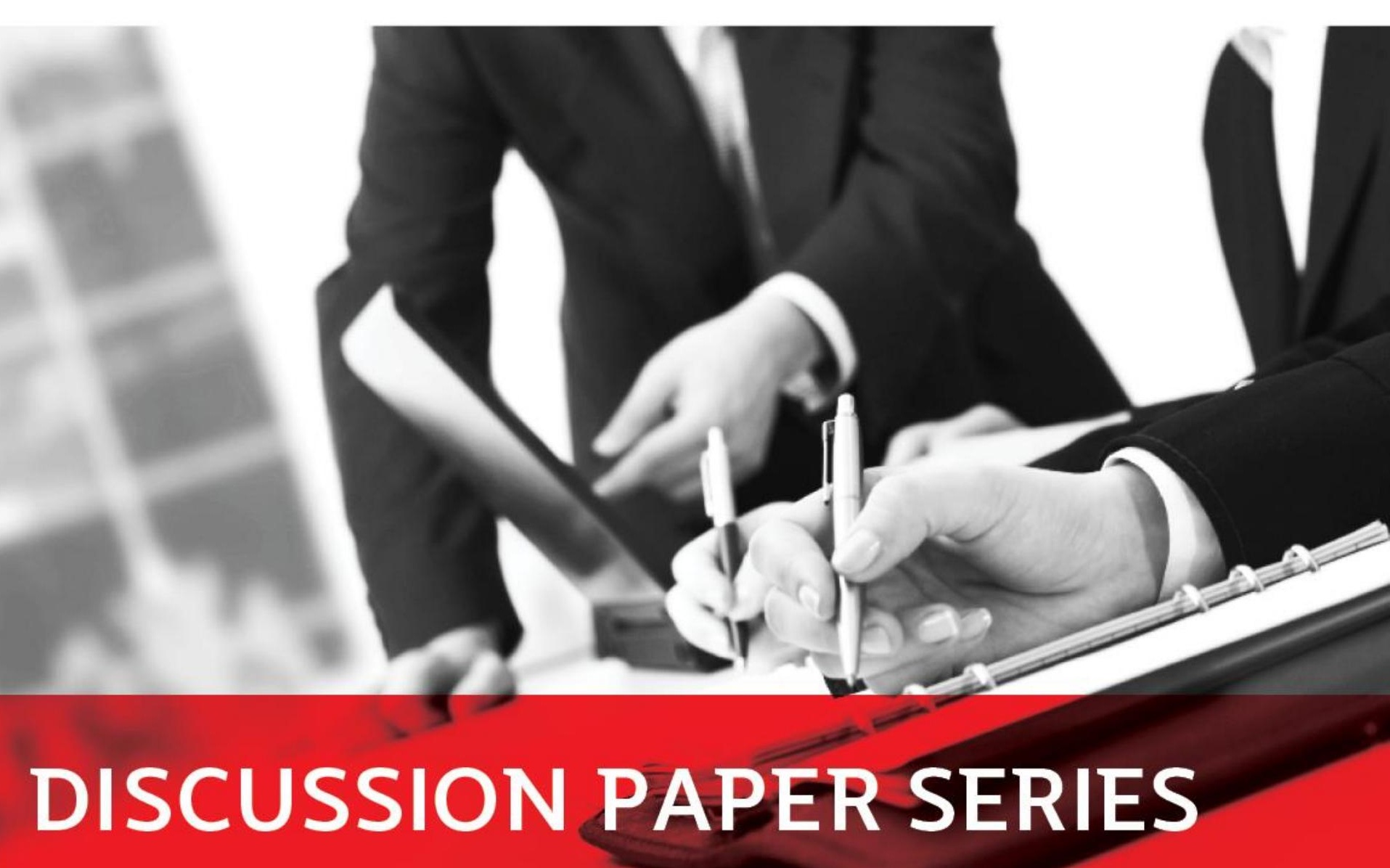

Finance and financial planning

Performance measurement in Australian water utilities: Current state and future directions

Alexandr Akimov and Paul Simshauser

No. 2018-02 


\title{
Performance measurement in Australian water utilities: Current state and future directions
}

\author{
Alexandr Akimov ${ }^{1}$ \& Paul Simshauser \\ Griffith Business School, Griffith University
}

\section{Abstract}

Ensuring universal and affordable water supply is a central objective of government. An efficient water supply sector plays a primary role in ensuring this objective is met. Scale economies and capital-intensive immobile assets means monopoly emerges as the dominant organisational form, and when combined with an essential character, a strong case exists for economic and technical regulation. Yet diversity in water service provider scale means economic regulation, which is costly, is not always viable. A comprehensive performance monitoring and reporting regime for water service providers is thus crucial. It is crucial for oversight of unregulated entities, and for regulated entities in generating competition by comparison. In this article, we undertake an expansive literature review and summarise approaches to performance measurement by the water industry. Academic literature reveals researchers have centered their approach using comprehensive methods such as Data Envelopment Analysis and Stochastic Frontier Analysis. With the exception of the Victorian Essential Services Commission, the Australian Industry persists with partial indicators. Given water and sewerage price increases of more than $100 \%$ in real terms from 2005-2014 we find a strong case for implementing advanced methods to address the task of providing a holistic picture of utility performance.

Key words: Benchmarking, water utilities, performance measurement, productivity

JEL Codes: G38, L95, L25

\footnotetext{
${ }^{1}$ Corresponding author
} 


\section{Introduction}

Ensuring universal, sustainable and affordable access to water and wastewater services is a central objective of government. An efficient water supply sector plays a primary role in ensuring this overall objective is met. The Productivity Commission (2011) outlines a number of more specific objectives for the urban water sector including water security, good public health outcomes, flood mitigation and minimisation of environmental impacts. Water affordability is also an important focus for Australian regulators, since the growth of water and sewerage charges has consistently outpaced the inflation rates in Australia since 2000 (See Figure 1).

Figure 1. Water and sewerage prices vs inflation

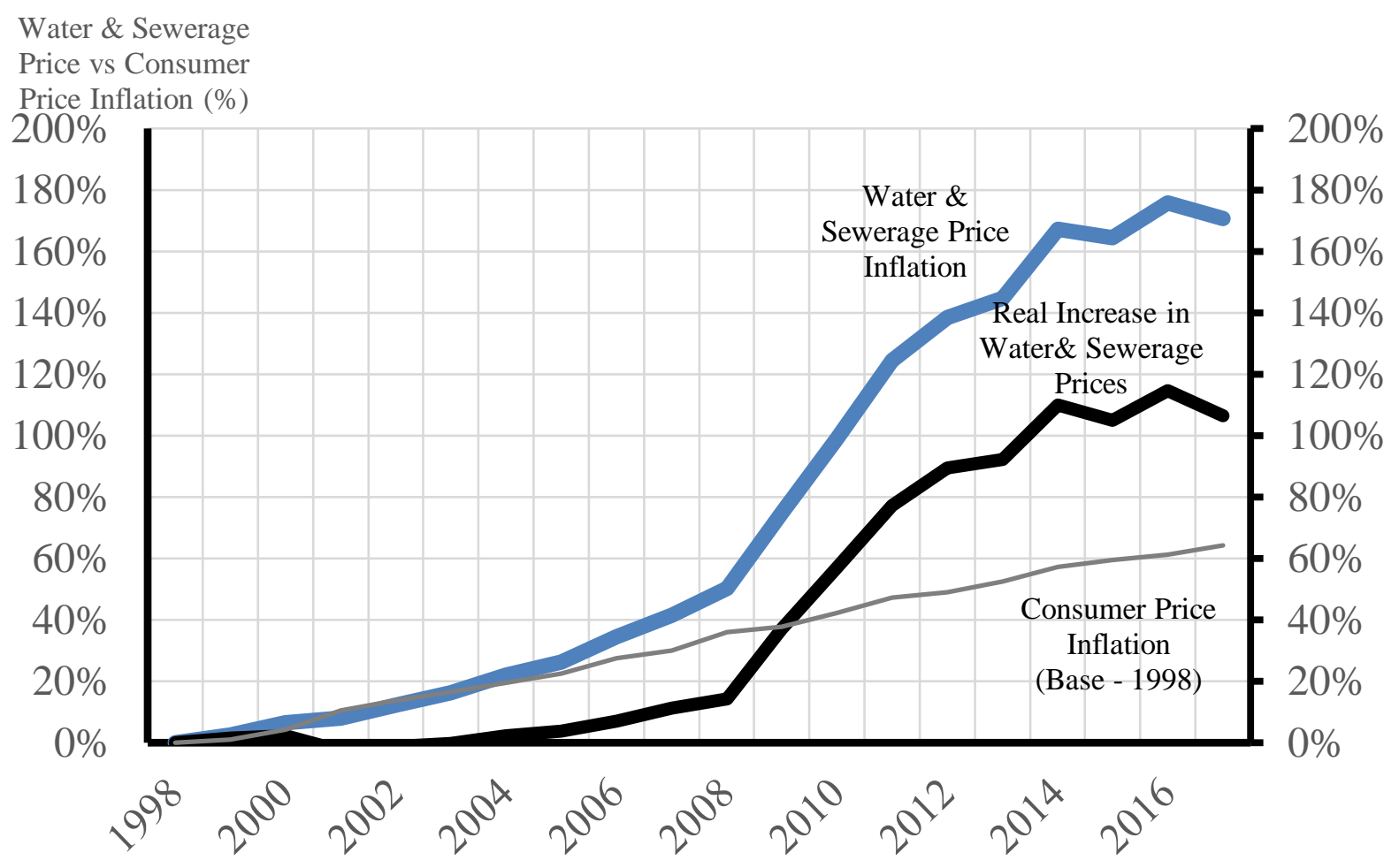

Source: Australian Bureau of Statistics

Industrial structure and institutional arrangements associated with the water sector varies around the world as a result of the various activities that water utilities undertake as well as utility size, geographical coverage, number of customers, involvement of the private sector, scope of competition and extent of regulation. In general, activities include bulk water collection and storage; bulk water transfer and distribution; water treatment; reticulation and retail supply; sewerage collection, distribution and treatment; drainage and irrigation (Abbott and Cohen, 2009). Table 1 provides a list of key activities of water supply and wastewater industry. 
Table 1. Key activities of water supply and wastewater industry ${ }^{1}$

Water and wastewater supply chain

\begin{tabular}{|c|}
\hline $\begin{array}{c}\text { Water source } \\
\text { (catchment management, collection and } \\
\text { storage) }\end{array}$ \\
\hline Bulk water transfer \\
\hline Water treatment \\
\hline Water distribution (trunk mains) \\
\hline Water distribution (reticulation) \\
\hline Customer service (water and wastewater) \\
\hline Sewerage reticulation \\
\hline Sewerage transfer \\
\hline Sewerage treatment \\
\hline Residuals management \\
\hline
\end{tabular}

Other potential activities

\begin{tabular}{|c|}
\hline Drainage \\
\hline Irrigation \\
\hline Land and resource management \\
\hline Flood management \\
\hline $\begin{array}{c}\text { Standard setting, regulation and policy } \\
\text { development }\end{array}$ \\
\hline
\end{tabular}

Operating conditions have a strong impact on the manner in which water and sewerage utilities conduct their business. Depending upon where water is sourced, technologies applied to purify water differ. Furthermore, environmental factors such as geography, topology and geology, and demographic factors such as customer characteristics also strongly impact the business of water and sewerage service providers.

The water and wastewater sector provides services with characteristics that differentiate them from other industries; viz. the sector provides services that: (i) are irreplaceable; (ii) must handle heterogeneous inputs; (iii) have potential for economies of scale and scope and associated process savings; (iv) have asset capacity designed for peak demand; (v) have long-lasting and high-value assets with limited mobility; (vi) have long-term capital recovery; and (vii) have low elasticity between price and demand (De Melo Baptista, 2014). Moreover, water has very high transportation costs and this limits the economics of supply networks (by comparison to electricity networks, for example). These industry characteristics result in natural local/regional monopoly emerging as the dominant organisational form for water and sewerage services. ${ }^{2}$ In some cases the industry is vertically integrated, while in others organisational form clusters around 1). bulk supply and 2). distribution/retail. Either way, the presence of dominant monopoly supply provides a strong case for economic regulation of the industry. ${ }^{3}$ And when monopoly supply as a dominant organisational form is combined with the essential service nature of water supply, it heightens the crucial role of performance monitoring and reporting.

2 We note however that an emerging business model is the "private service provider" which effectively utilises common bulk water monopoly infrastructure and then competes with the incumbent distribution-retailer in new property estates or large highrise dwellings, in some cases maximising recycled resources. See for example "Flow Systems" in New South Wales.

3 We should highlight that regulation also places a cost burden on industry. While the regulation of water supply quality is generally accepted as a necessity regard and thus regulation cannot feasibly be 
Of course, benchmarking and performance analysis plays an important role in any organisation irrespective of the industry or form of ownership. Knowing how well an organisation is operated, and where it stands in comparison to other organisations of a similar kind helps managers, owners and decision-makers to adjust existing practices and set future targets. But this has a special application in the implementation of water policy given the dominant industry form is monopoly supply (whether vertical monopoly or unbundled monopoly supply segments). Information on the operation of water/sewerage systems, investments, inputs and outputs can help to establish good management practices, effective oversight and enhanced fiscal sustainability.

This article is structured as follows; Section 2 provides an overview of benchmarking methods while Section 3 presents a brief history of water utility performance measurement in Australia along with a description of the contemporary state of affairs in various jurisdictions. Section 4 discusses global benchmarking practices including international frameworks and notable overseas national/regional frameworks. Section 5 describes academic studies performed in relation to Australian water utilities, with a brief description of methodologies and major findings. Section 6 provides an overview of existing studies of water utilities outside Australia. Concluding remarks and policy recommendations follow.

\section{Benchmarking and performance evaluation methods}

Evaluating the performance of water utilities is inherently difficult due to the diversity in organisational form, boundaries of the firm, and as we observe later in this article - the immense diversity in the scale of water service providers; for example in Queensland the largest utility has 550,000 household accounts (i.e. Queensland Urban Utilities which services large areas of Southeast Queensland) and has been unbundled from the bulk water supply provider ${ }^{4}$, whereas the smallest water service provider has 118 household accounts (viz. Mapoon Shire Council, remote regional Queensland) and is a fully integrated water service provider. Figures 2 and 3 provide data from Queensland and illustrates the enormous variation in scale among utilities in terms of number of serviced connections, as well as length of water mains used to service these connections. Note also that the data displayed, the trend line in Figure $2(R=0.9781)$ indicates a very strong relationship between connection numbers and length of water mains, but expansion of the $x$ - and $y$-axis (see Figure 3 ) illustrates the extent of variation amongst sub-scale providers.

\footnotetext{
${ }^{4}$ SEQWater is the Bulk Water Supplier to all 'Retailer-Distributor' businesses in Southeast Queensland, including Queensland Urban Utilities.
} 
Figure 2. Number of connections vs length water mains (FY2014-FY2018)

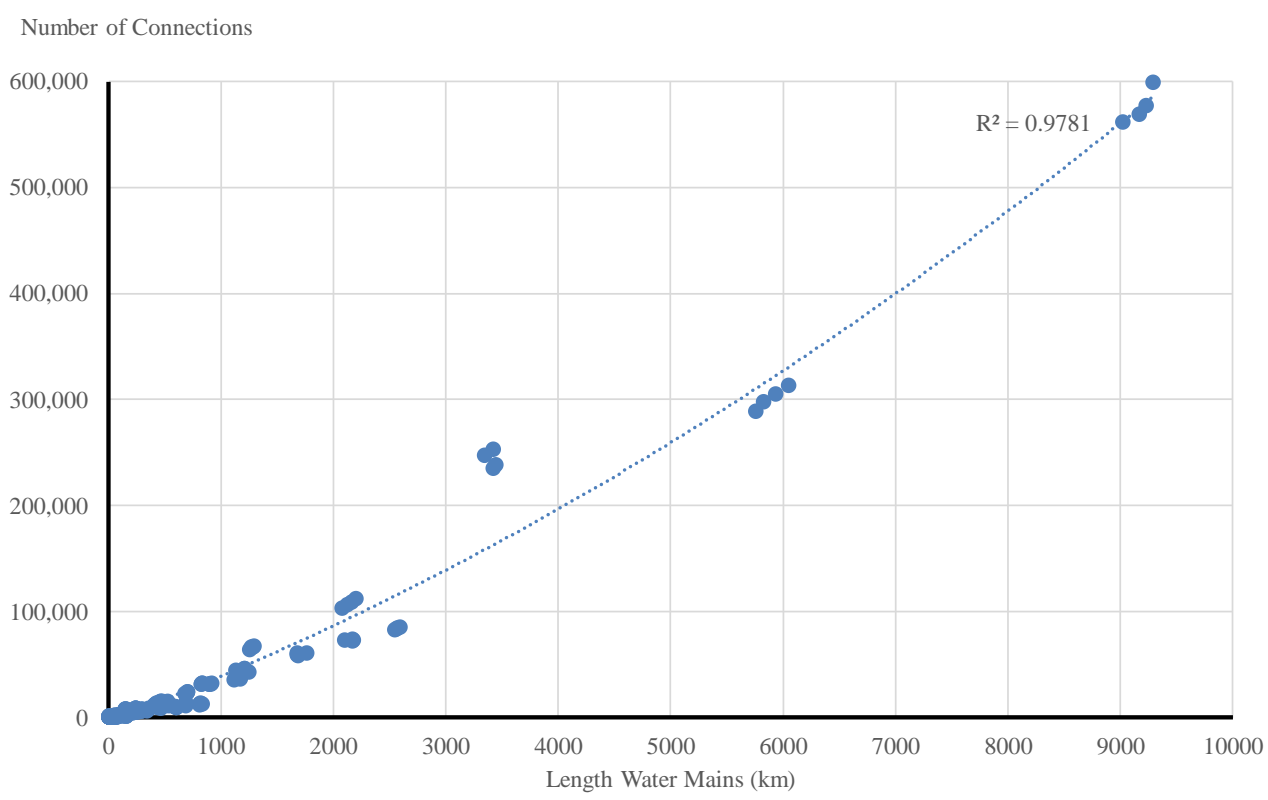

Source: Statewide Water Information Management System, QId Water Directorate (SWIMS).

Figure 3. Small providers: number of connections vs length water mains

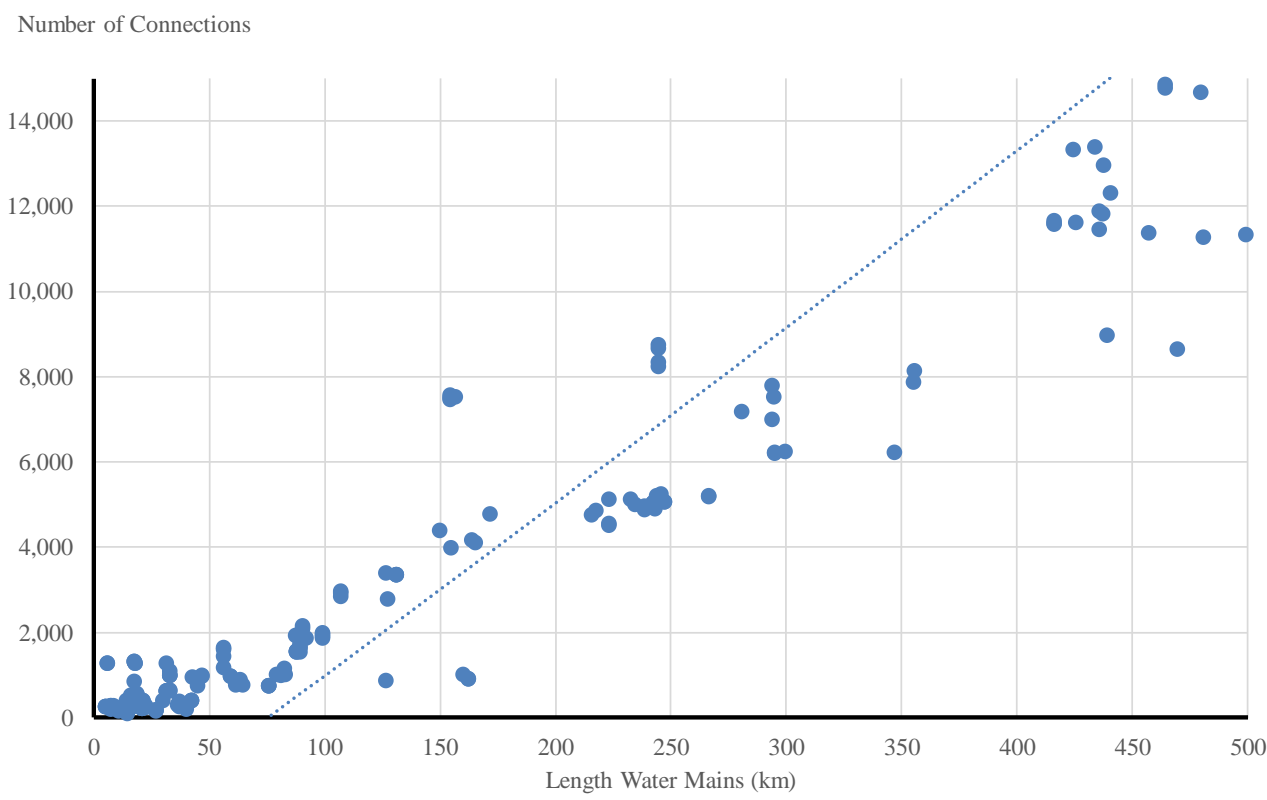

Source: SWIMS.

In recognition of the complexity of evaluating water utility performance, a variety of methodologies have been developed to address specific issues. Berg (2010) suggested the following typology of methods:

(i) Core indicators (also known as partial indicators).

(ii) Performance scores based on production or cost estimates (total methods).

(iii) Performance relative to a model company (engineering approach).

(iv) Process benchmarking that involves detailed analysis of operating characteristics.

(v) Customer survey benchmarking (identifying customer perceptions). 
There is an extensive industry and academic literature that discuss the merits of these methods, as well as outlining the application of these methods in various regions and contexts. A brief introduction to each method follows.

Partial indicators are usually presented in ratio form and reflect operational and financial characteristics of the organisation concerned. For water utilities, examples may include ratios such as the number of connections per worker, the proportion of unaccounted water, and operating expenses (Opex) per connection (see Figure 4).

\section{Figure 4. Water operating cost per property connected by water service provider}

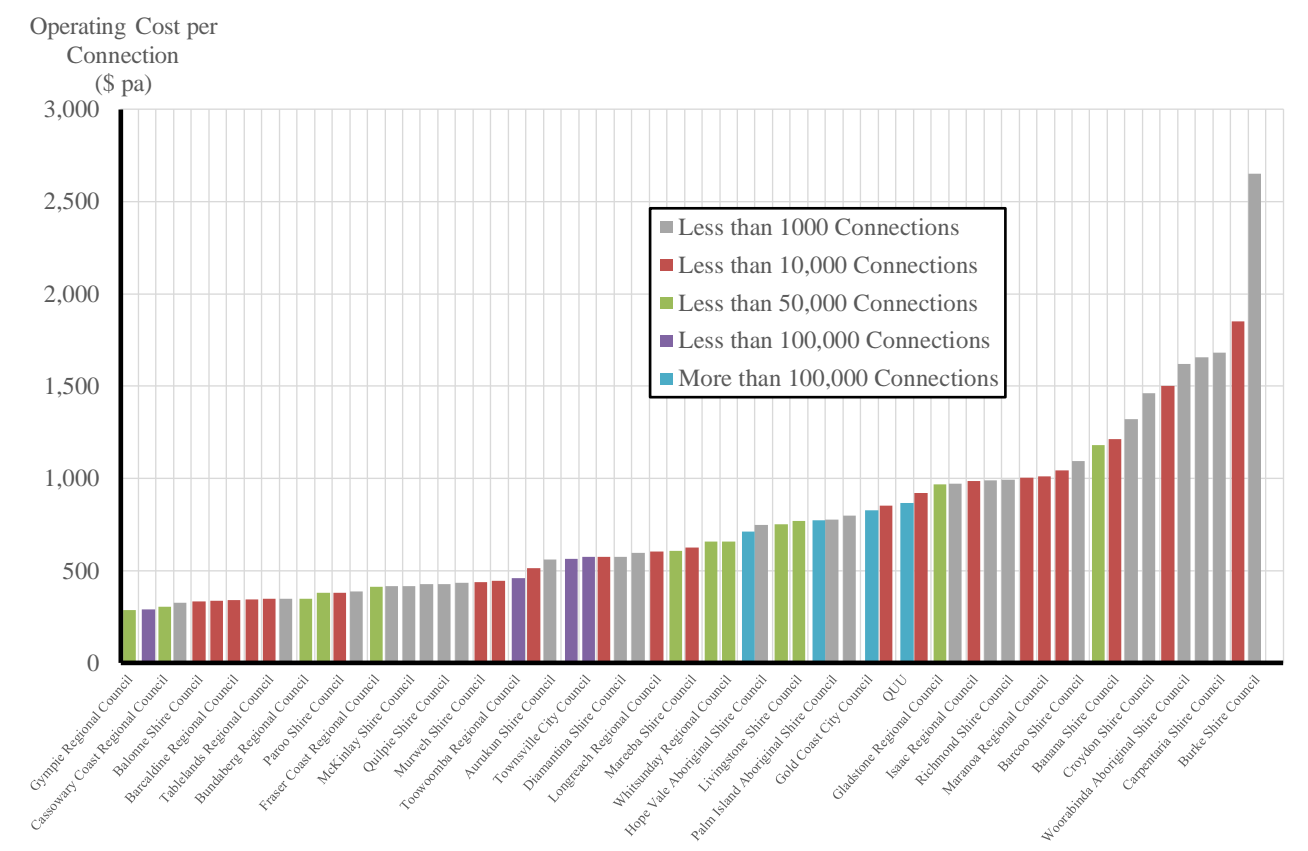

Source: SWIMS.

These indicators are popular reflecting their relative simplicity in terms of data collection, reporting, interpretation and ease of inter-company comparison. The major disadvantage of these indicators is the narrow focus of individual ratios on certain segments of operation and their ability to under-interpret scale economies and consequential impacts. For example, a water utility might be 'best in class' in terms of operating cost per connection yet have the worst conservation and environmental performance due to high system losses. Alternatively, a water utility may appear to have best in class 'Cost-to-Serve' but poor customer service. Furthermore, high sales volumes may reflect excessive household consumption due to poor tariff design and lack of conservation mechanisms. To address such problems, a large number of indicators have to be looked at simultaneously, including indices that reflect overall performance (i.e. created by estimating a weighted average of key performance indicators). However, there are also a number of problems with indices, including subjectivity in the selection of key indicators and the weighting procedure, and difficulties in the interpretation of the overall index values. A specific example on how it can be difficult to use partial indicators to assess the performance of a water utility, or to compare it with another utility can be drawn from our Queensland Water Service Provider data set (FY2014-FY2018). In the 2016 reporting year Logan City Council had 109,000 
connections whereas Townsville City Council had 84,300 connections. Conversely, Townsville had a larger length of mains to maintain at 2,573.4 $\mathrm{km}$ versus 2,162 km for Logan. But a striking difference comes from water consumption levels. The volume of water supplied by Logan City Council was 19,704.8ML whereas Townsville was more than twofold that amount, at 44,392 ML. If we derive water supplied per connection ratios from the above numbers, Townsville's water supplied per connection is $500+\mathrm{kL}$ per connection, almost three times the Logan result of $180 \mathrm{~kL}$ per connection and more than two times the state-wide reference volume of $200 \mathrm{~kL}$. Given sales volume is frequently used as a denominator in key partial analysis indicators, sources of such a dramatic discrepancy must be considered carefully before any conclusions are drawn. Figure 5 highlights the extent in the variation of water supplied per residential connection among Queensland utilities. The bars show average water supplied (FY2014-2018) while the markers show minimum annual water supplied (triangles) and maximum annual water supplied (squares).

Figure 5. Water use in Queensland by water service provider (FY2014-FY2018)

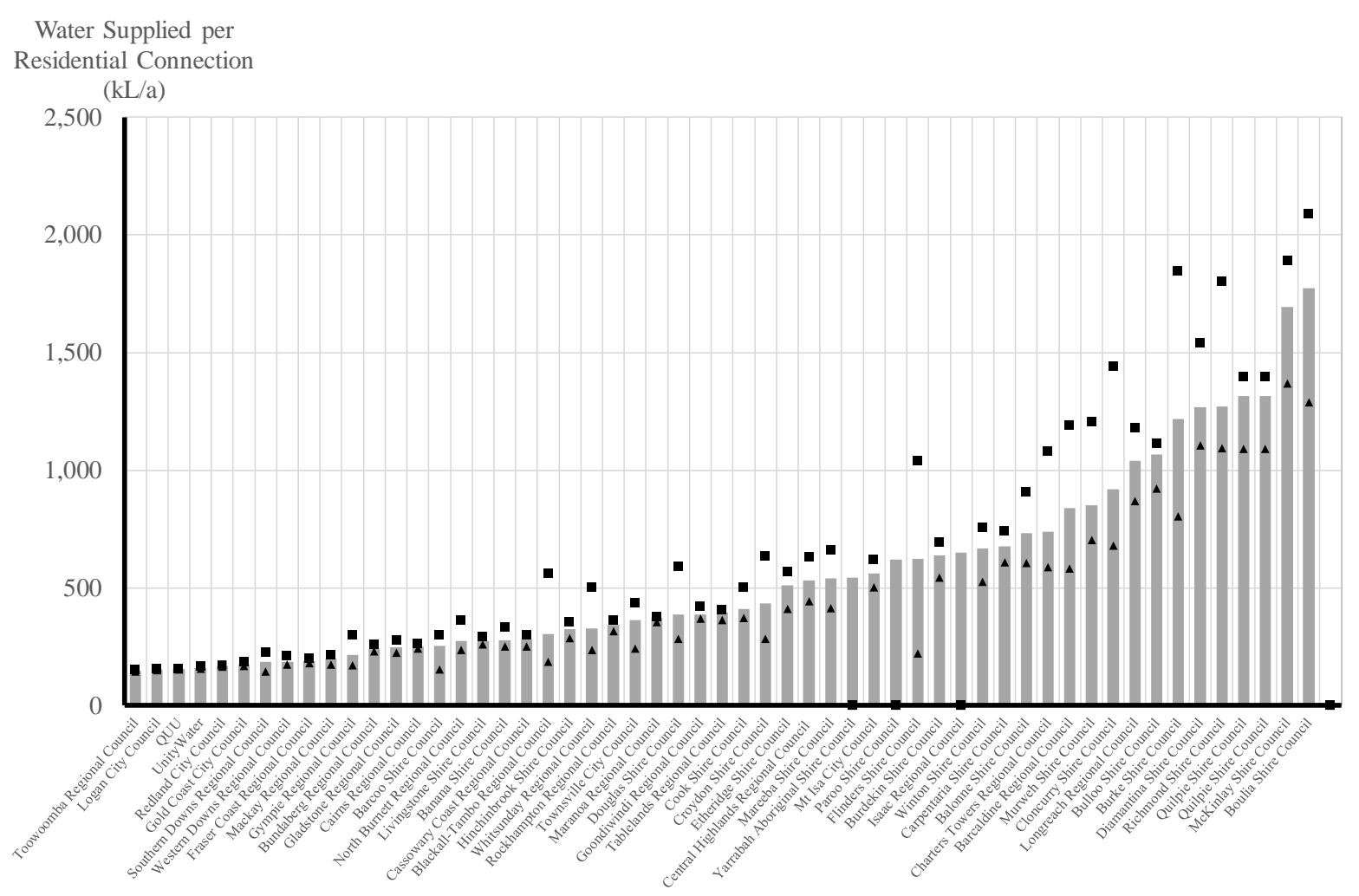

Source: SWIMS.

Total methods seek to identify relative performance of an individual utility within a particular cohort of utilities. A framework for identifying the best and worst performers has to be created, which includes the selection of inputs/outputs and explanatory/dependent variables. Three groups of methods may be applied to handle the data: (i) non-frontier parametric/statistical methods, such as Ordinary Least Squares (OLS) regressions or panel data techniques; (ii) frontier parametric methods of stochastic frontier analysis (SFA); (iii) frontier non-parametric methods, such as data envelopment analysis (DEA). Appendix I provides a detailed explanation of DEA and SFA methods for readers unfamiliar with the techniques. These methodologies assist in establishing whether, for example, some utilities produce 
similar levels of output at higher cost (relative cost-inefficiency) or produce smaller levels of output given similar levels of input (technical inefficiency), or whether the output/input ratio varies for firms of different size (scale inefficiency).

Total methods have been especially popular in the academic literature. However, application by governing bodies has been limited. In our view, this is most likely due to their relative complexity compared to partial methods, particularly in terms of inconsistent application of the methodology and interpretation of results, and the complexity in identifying relevant utility cohorts and confidence in data. Results of the estimations have to be treated with particular care by policymakers to avoid backlash from utilities, as there can be valid reasons why certain utilities perform poorly during specific time periods (e.g. drought conditions, policy or political distortions). However, when handled with care these methods are very useful for promoting yardstick competition amongst providers.

Through the course of this research, we did identify one applied regulatory example of the use of Total Methods in the water industry in Australia. In 2012 the Essential Services Commission (ESC) of Victoria originated a study to assess comparative productivity levels of Victorian utilities against productivity levels observed in other Australian jurisdictions using Total Methods, including Total Factor Productivity indices and Stochastic Frontier Analysis. The study found above average performance of major utilities and below average performance of non-major utilities in Victoria (ESC, 2012). In an updated study in 2014, the analysis found a trend of improving technical efficiency amongst Victorian utilities (Economic Insights, 2014).

Engineering approach is based on the modelled benchmark performance of a utility. An optimised engineering and economic model is applied to each individual utility according to its key parameters such as population density, topology and customer profile. The approach has been used in some countries such as Chile and Argentina. However, it has not been widely applied in academic and practical contexts due to the complexity of creating and maintaining the requisite models for highly diverse (and frequently small-scale) organisations and their associated data inputs (Berg, 2010).

Process benchmarking is applied to the individual stages of production/service delivery in the service production chain. A clear advantage of this methodology is the ability to examine problematic areas of the organisation, and the ability to share best practice amongst participating utilities. On the other hand, the method is not suitable for relative performance measurement and ranking. Indeed, it assumes the strong intervention of the benchmarking party into the processes and managerial decisions of individual utilities, and is costly to perform on a regular basis. Moreover, implementation of process changes can be based on the specific preferences of the benchmarking body, often susceptible to an inappropriate 'one size fits all' solution. Dollery and Akimov (2008) and Dollery, Wallis and Akimov (2010) have documented the pitfalls of the 'one fits all' solutions previously applied in Queensland local government reforms. As Figure 6 and 7 clearly demonstrate, utilities may face considerably different operating environment (for example, length of mains to be serviced), which is reflected in differences in their Opex. Therefore, any process benchmarking initiatives have to carefully consider those operating factors. 
Figure 6. Water Opex vs length of water mains (FY2014-FY2018)

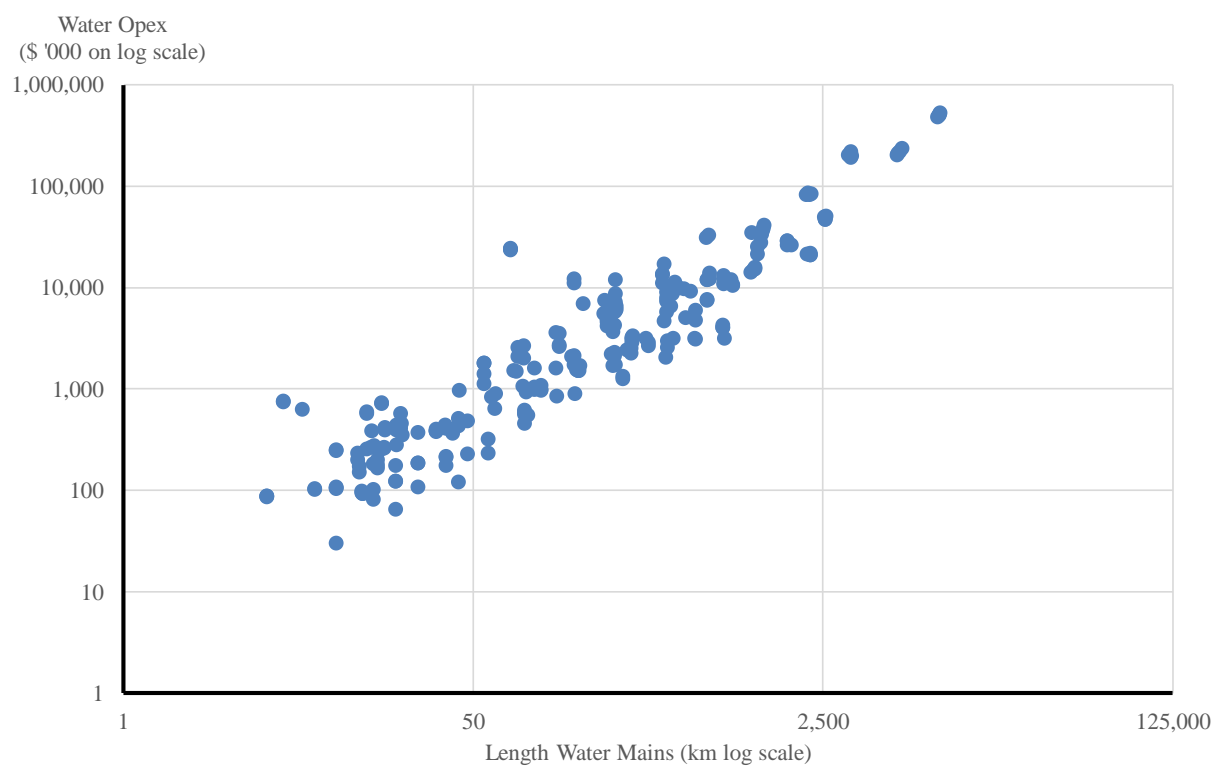

Source: SWIMS.

Figure 7. Sewerage Opex vs length of sewerage mains (FY2014-FY2018)

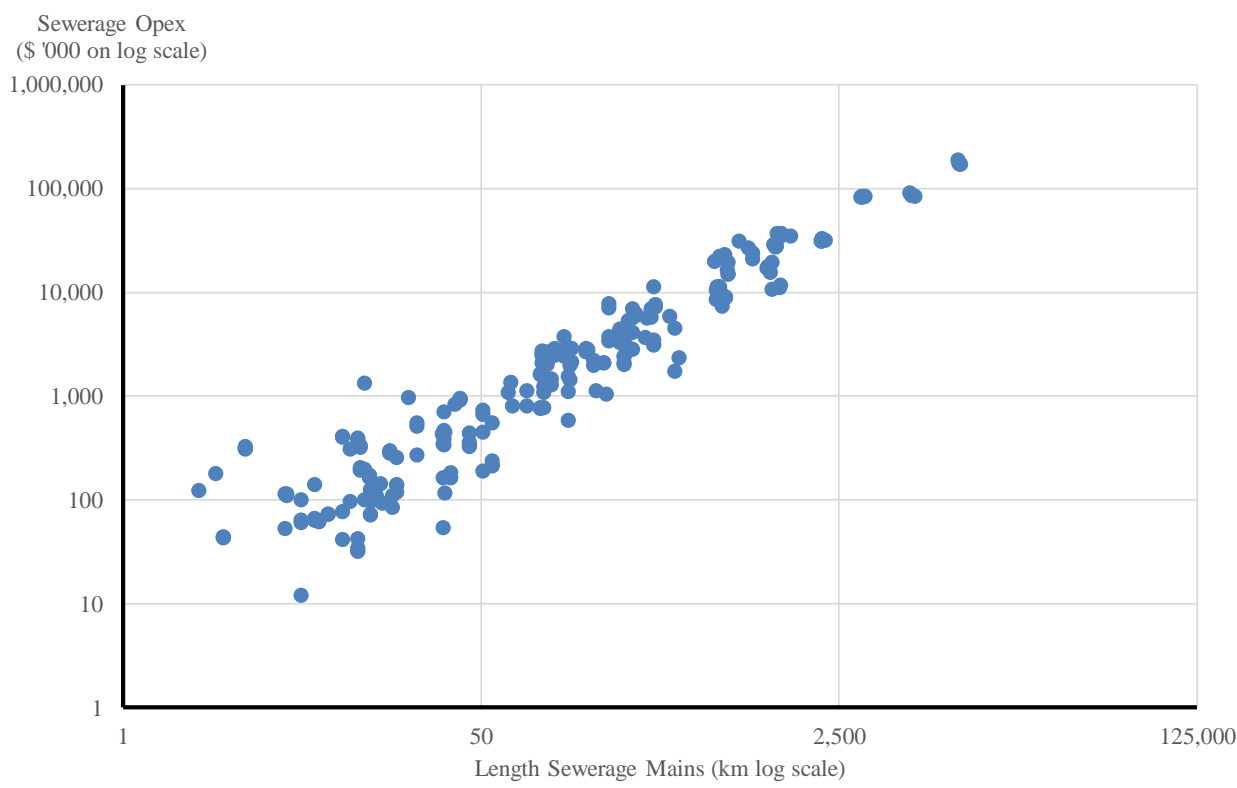

Source: SWIMS.

Customer survey benchmarking uses the responses of water utility users to evaluate the performance of a utility. Although there is clear benefit in using such customer-focused performance measuring criteria, there are deficiencies when used in isolation. First, there are often issues with surveying processes and survey completion rates. Second, survey results reflect sentiment of respondents and a true comparative performance of the utility. This may spur utilities to direct remedial efforts into marketing activities rather than focusing on the efficient delivery of service. Third, respondents may not have an adequate basis on which to evaluate the performance of a local utility if they have not been exposed to alternatives. Put differently, some users might see no problems with the 
service quality unless they could see and experience how other service providers operate, and vice versa.

The current article aims to achieve a number of goals. First, it examines current performance benchmarking practices in Australia and overseas, including information on the scope and scale of data collected and reported by government and non-government organisations. The merits of these practices are briefly discussed with a view to establishing alternative data collection requirements in Australia. Second, the article provides a review of the relevant academic literature in an effort to identify which if any of the existing modern methodologies might be implemented. The focus is on more recent studies, including those published on Australian utilities.

\section{Urban water utility performance measurement in Australia}

The urban water utility sector in Australia has not always been the focus of government policy. The first landmark document, 'A Water Resource Policy', dates from 1994 and was produced by the Council of Australian Governments (COAG). Its main emphasis was bringing water prices to a cost recovery level in order enhance allocative and dynamic efficiency, and thus formed part of the broader "Hilmer" suit of microeconomic reforms (see for example Nelson et al 2010). The document also called for the reform of water service providers with the aim of delivering water as efficiently as possible (Council of Australian Governments, 1994). The need for measures that would allow comparisons of inter-agency performance was also voiced. As part of the broader National Competition Policy, COAG encouraged government utilities to adopt corporate structures and embrace market pricing. The state of Victoria responded with a substantial reform of the urban water sector by consolidating its 130 local government water utilities into 18 urban government corporation-like authorities (Byrnes et al., 2010). Other states, such as New South Wales (NSW) and Queensland (QLD), chose not to implement radical institutional reform but rather focused on water pricing as a means to enhance industry (financial) sustainability and allocative and dynamic efficiency.

The second blueprint document was COAG's 2004 National Water Initiative (NWI) (Council of Australian Governments, 2004). It represented 'a shared commitment by governments to increase the efficiency of Australia's water use, leading to greater certainty for investment and productivity, for rural and urban communities, and for the environment' (Department of Agriculture and Water Resources, 2017).

The National Water Commission (NWC) was established to implement the reform. To address the issue of performance measurement, a national framework for the benchmarking of pricing and service quality for metropolitan, non-metropolitan and rural water utilities was agreed. The first National Performance Report (NPR) for urban utilities was released in 2007. The urban utilities were originally grouped into two categories, 'Major Urban Utilities' and 'Non-Major Urban Utilities', with more than 50,000 connected properties or with 10,000 to 50,000 connected properties, respectively. Interestingly, smaller utilities with less than 10,000 connected properties were not subjected to NWC reporting requirements. One reason cited was that such utilities existed to provide essential services to remote communities and scrutinising the efficiency of their operations was not appropriate (ACIL Tasman, 2005). In later reports, 
urban utilities were placed into four groups, with (i) 10,000 to 20,000 connections, (ii) 20,000 to 50,000 connections, (iii) 50,000 to 100,000 connections, and (iv) over 100,000 connections.

In 2014, the NWC was abolished and its functions transferred to other agencies. Performance reporting now rests with the Bureau of Meteorology. The number of indicators has evolved over time with the latest report presenting 182 individual metrics and sub-indicators for 79 retail utilities and seven bulk water suppliers (Bureau of Meteorology, 2017). These performance indicators are grouped into seven categories, as presented in Table 2.

Strengths of the framework include the fact that indicators are easy to measure and understand. Moreover, in our view the framework is comprehensive with a notable attempt to address environmental factors. In this aspect, it is ahead of the majority of frameworks adopted around the world as we later explain in Section 3.

The framework does however contain weaknesses, viz. most indicators (apart from five financial measures) are expressed in absolute non-percentage form. Haider et al. (2014) suggest this might be attributed to a basis of similar water resources and environmental conditions. This assumption is questionable because climatic conditions within regions and across Australia vary dramatically. In any case, this reporting format is not conducive to the comparison of utilities which vary substantially in scale. Moreover, the scope of indicators related to performance of sewerage services is limited. 
Table 2. 2016 NPR categories of indicators and sub-indicators

\begin{tabular}{|c|c|c|}
\hline $\begin{array}{c}\text { Category } \\
\text { (No. of indicators } \\
\text { and sub-indicators) }\end{array}$ & Subcategory & $\begin{array}{l}\text { No. of indicators } \\
\text { and sub- } \\
\text { indicators in the } \\
\text { subcategory }\end{array}$ \\
\hline \multirow{4}{*}{ Water resources (51) } & Sources of water & 9 \\
\hline & Uses of water supplied & 21 \\
\hline & Sewage collected & 9 \\
\hline & Uses of recycled water and stormwater & 12 \\
\hline \multirow{6}{*}{ Asset (13) } & Water treatment plants & 1 \\
\hline & Other water assets & 4 \\
\hline & Sewerage assets & 1 \\
\hline & Water main breaks & 2 \\
\hline & Water losses & 3 \\
\hline & Sewerage breaks and chokes & 2 \\
\hline \multirow[t]{12}{*}{ Customers (27) } & Connected properties and population & 7 \\
\hline & Customers & 1 \\
\hline & Water service complaints & 2 \\
\hline & Water quality complaints & 2 \\
\hline & Sewerage service complaints & 2 \\
\hline & Billing and account complaints & 2 \\
\hline & Total water and sewerage complaints & 2 \\
\hline & Water interruption frequency & 2 \\
\hline & Restrictions or legal action for non-payment of water bill & 4 \\
\hline & Connect time to a telephone operator & 1 \\
\hline & Average duration of unplanned water supply interruptions & 1 \\
\hline & Average sewerage interruption & 1 \\
\hline \multirow[t]{4}{*}{ Environment (21) } & Comparative sewage treatment levels & 6 \\
\hline & Net greenhouse gas emissions & 12 \\
\hline & Sewer overflows & 2 \\
\hline & Biosolids reuse & 1 \\
\hline \multirow[t]{3}{*}{ Pricing (26) } & Residential tariff structure & 20 \\
\hline & Annual bill (based on $200 \mathrm{kl}$ residential water supplied) & 4 \\
\hline & $\begin{array}{l}\text { Annual bill (based on average residential annual water } \\
\text { supplied) }\end{array}$ & 2 \\
\hline \multirow[t]{12}{*}{ Finance (39) } & Revenue & 9 \\
\hline & Written down replacement costs of fixed assets & 2 \\
\hline & Costs & 8 \\
\hline & Capital expenditure & 7 \\
\hline & Economic real rate of return & 3 \\
\hline & Dividends & 2 \\
\hline & Net debt to equity & 1 \\
\hline & Interest cover & 1 \\
\hline & Net profit after tax & 2 \\
\hline & Community service obligations (CSOs) & 1 \\
\hline & Capital works grants & 2 \\
\hline & Revenue from CSOs & 1 \\
\hline Health (4) & Water quality compliance & 4 \\
\hline
\end{tabular}

Source: Bureau of Meteorology (2017)

Australian states and territories have taken diverse approaches to industry reform. Urban utility industry structure varies from state to state, as does performance reporting, as illustrated by the following examples.

In the Australian Capital Territory (ACT) Icon Water is the sole water utility, and is owned by the ACT government. It publishes a number of its own reports and supplies data for the NPR. Its annual report 
contains, among other things, audited financial statements. Icon Water's Drinking Water Quality Reports focus on the quality of water and water treatment (see Icon Water Limited, 2016).

Similarly, in the Northern Territory Power and Water Corporation is the sole licensed water utility servicing five major centres and 13 remote communities. It publishes its own annual report (see Power and Water Corporation, 2016), other ad hoc reports and supplies data for the NPR. An annual report on water quality has been made available until 2012, and the latest Indigenous Essential Services Drinking Water Quality Summary Report is dated 2011 (Power and Water Corporation, 2011).

In Tasmania, the sole provider of water and sewage services since 2013 has been TasWater ${ }^{5}$. It was formed as a result of the merger of the water and sewerage services previously delivered by 28 local councils and three bulk water authorities with ownership in proportion to assets contributed. TasWater supplies performance data for the NPR and the Tasmanian Economic Regulator publishes regular state-of-the-industry reports in which it details the performance of TasWater according to the indicators supplied for inclusion in the NPR.

In South Australia, the state government differentiates providers into two categories: major retailers (> 50,000 connections) and other retailers ( $<50,000$ connections). The only utility that fits into the former category is SA Water. SA Water supplies water services to $99 \%$, and sewerage services to $87 \%$ of South Australia's population. A further 63 small water service providers supply the remainder of South Australia's population. Performance reporting requirements differ between the major retailer and the small water service providers. SA Water supplies comprehensive data for the NPR, and publishes an annual report with audited financial statements. The Essential Services Commission of South Australia (ESCOSA) also publishes an annual regulatory performance report in which it focuses on customer services and water supply reliability (ESCOSA, 2017). For the other retailers, ESCOSA publishes a Minor and Intermediate Retailers Regulatory Performance Report, which contains only limited performance information (ESCOSA, 2016).

In Western Australia, urban water and sewage services are delivered by four water and sewage service providers, namely, Water Corporation, Aqwest, Busselton Water and City of Kalgoorlie-Boulder. Water Corporation is the principal water and sewage services provider, covering practically the whole state and over one million properties. It has branches in Perth, Bunbury, Albany, Karratha, Geraldton, Northam and Kalgoorlie. Interestingly, Water Corporation supplies data for the NPR in disaggregated form, separately for the areas of Perth, Mandurah, Australind/Eaton, Geraldton, Albany, KalgoorlieBoulder (Water), Busselton (Sewage) and Bunbury (Sewage). Aqwest and Busselton Water are the other water services providers in the state, while City of Kalgoorlie-Boulder provides sewerage services for the local Kalgoorlie area. All three provide performance indicators for inclusion in the NPR. In addition, the Economic Regulation Authority of Western Australia (ERA) annually reports a range of indicators for all schemes involving over 1,000 connections. These are largely in line with NPR

\footnotetext{
${ }^{5}$ Tasmanian Water and Sewerage Corporation.
} 
indicators for water resources, assets and customers. The most recent report, of 2015, covers 32 drinking water schemes and 22 sewerage schemes (ERA, 2016). In addition to these four major water and sewerage providers, there are 30 very small licensed providers, which mainly service mining operations and are not subject to performance reporting.

In Victoria, there are 17 urban water utilities, including 16 retail utilities and one (Melbourne Water) that is solely a bulk water provider. Of the 16 retail utilities, three service the Melbourne metropolitan area, and the other 13 are regional utilities. Originally earmarked for privatisation, all water utilities are owned by the state government but operate as genuinely standalone entities responsible for their own management and performance through Boards of Directors as representatives of their ultimate shareholders.

All of Victoria's urban utilities supply data for the NPR. In addition, the Essential Services Commission of Victoria (ESC) publishes an annual Water Performance Report with an emphasis on indicators of water usage and price trends, customer service, network reliability, drinking water quality and environmental indicators. ESC Reports largely use indicators adopted in the NPR (ESC, 2016).

In New South Wales, there are three state-owned metropolitan water utilities and 92 regional water utilities. The three metropolitan water utilities include two retail water service providers, Sydney Water and Hunter Water, and one bulk water provider, Water NSW. The regional water utilities operate mainly under the Local Government Act 1993. The Department of Primary Industries is the principal regulator of these regional providers.

All 31 of the NSW water utilities that manage over 10,000 connections supply data for inclusion in the NPR, and all water utilities provide data for inclusion in the NSW Water Supply and Sewerage Benchmarking Report. In these reports, water utilities are split into four groups according to their size: (i) 200 to 1,500 connections; (ii) 1,501 to 3,000 connections; (iii) 3,001 to 10,000 connections; (iv) utilities over 10,000 connections. The reported indicators are placed into four groups, covering 1) utility characteristics, 2) social characteristics, 3) environmental characteristics, and 4) economic characteristics. There are 23 indicators common to both water and sewerage service providers, 56 indicators solely for water providers, and 57 for sewerage providers. Many but not all of the report indicators are in line with NPR. There are some NSW-specific indicators in all areas of reporting (NSW Government, 2016).

The NSW Water Supply and Sewerage Benchmarking Report also provides additional information, albeit not always in a user-friendly format. For example, it reports on the condition of infrastructure assets, further performance indicators for water and sewerage, and the water conservation initiatives of individual providers.

In Queensland, there were 180 registered water and sewerage service providers as of 1 January 2017 (Queensland Government, 2017). This includes many entities that are not traditional utilities (Bureau of Meteorology, 2017). The Department of Energy and Water Supply is the water supply regulator for Queensland. Of the 76 providers that were required to report a set of key performance indicators for annual reporting, 73 providers supplied data (Queensland Government, 2016). In the report, 
Queensland water and sewerage utilities are split into three groups: (i) utilities with up to 1,000 connections; (ii) utilities with between 1,001 and 25,000 connections; (iii) utilities with over 25,000 connections. Three retail providers stand out in particular because they each service more than 200,000 properties: Queensland Urban Utilities servicing Brisbane, Unity Water servicing Moreton Bay and Sunshine Coast, and Gold Coast City Council servicing the Gold Coast. Their 65 reported indicators are split into six categories: 1) general (20 indicators); 2) water security (nine indicators); 3 ) finance (20 indicators); 4) customer (11 indicators); 5) environment (two indicators); 6) other (three indicators). A majority of the reported indicators, 41, are in line with the NPR, while there are 21 Queensland-specific indicators. As with the NPR, the majority of these unique indicators are presented in a raw absolute form. The 22 largest providers (with 10,000 connections or more) report to the NPR on a wider range of indicators.

In summary, performance reporting in Australia is largely based on the NWC framework, which uses an extensive set of measures mostly presented in raw non-ratio/non-percentage form. Some Australian states, such as NSW and QLD, provide separate reporting for the utilities that are not covered by the NPR. Moreover, both of these states report additional indicators to the ones listed in the NPR. The practice of reporting partial indicators is somewhat limited, and there are no sophisticated benchmarking methods in regular use such as total methods based on the frontier approaches.

There have been a number of ad hoc industry reports that have employed total factor productivity and stochastic frontier methodologies to analyse the water utilities in Victoria (ESC, 2012, 2015) and South Australian (KPMG, 2015). Table 3 summarises the scope of Australian industry reporting. 
Table 3. Water utility reports in Australia

\begin{tabular}{|c|c|c|}
\hline Source & Title & Scope \\
\hline \multicolumn{3}{|l|}{ Milestone documents/reports } \\
\hline COAG (1994) & A Water Resource Policy & National \\
\hline COAG (2004) & $\begin{array}{l}\text { Intergovernmental Agreement on a } \\
\text { National Water Initiative }\end{array}$ & National \\
\hline Productivity Commission (2011) & Australia's Urban Water Sector & National \\
\hline \multicolumn{3}{|l|}{ Performance benchmarking reports } \\
\hline $\begin{array}{l}\text { Bureau of Meteorology (annual, } \\
\text { latest in 2016) }\end{array}$ & $\begin{array}{l}\text { National performance report 2014-15: } \\
\text { Urban water utilities }\end{array}$ & National \\
\hline $\begin{array}{l}\text { Department of Primary Industries, } \\
\text { Water (annual, latest 2016) }\end{array}$ & $\begin{array}{l}\text { NSW Water supply and sewerage } \\
\text { benchmarking report 2014-15 }\end{array}$ & NSW \\
\hline $\begin{array}{l}\text { Department of Energy and Water } \\
\text { Services (annual, latest in 2016) }\end{array}$ & $\begin{array}{l}\text { Queensland service provider comparative } \\
\text { report, 2014-2015 }\end{array}$ & QLD \\
\hline QLD Water (annual, latest in 2016) & $\begin{array}{l}\text { Queensland's Urban Potable Water and } \\
\text { Sewerage Benchmarking Report 2014/15 }\end{array}$ & QLD \\
\hline $\begin{array}{l}\text { Essential Services Commission of } \\
\text { South Australia (annual, latest in } \\
\text { 2017) }\end{array}$ & $\begin{array}{l}\text { SA Water Regulatory Performance } \\
\text { Report 2015-16 }\end{array}$ & SA \\
\hline $\begin{array}{l}\text { Essential Services Commission of } \\
\text { South Australia (annual, latest in } \\
\text { 2017) }\end{array}$ & $\begin{array}{l}\text { Minor and Intermediate Retailers } \\
\text { Regulatory Performance Report 2014-15 }\end{array}$ & SA \\
\hline $\begin{array}{l}\text { Office of the Tasmanian Economic } \\
\text { Regulator (annual, latest in 2017) }\end{array}$ & $\begin{array}{l}\text { Tasmanian Water and Sewerage State- } \\
\text { of-the-Industry Report 2015-16 }\end{array}$ & TAS \\
\hline $\begin{array}{l}\text { Essential Services Commission of } \\
\text { Victoria (annual, latest in 2016) }\end{array}$ & $\begin{array}{l}\text { Water Performance Report: Performance } \\
\text { of Victorian urban water and sewerage } \\
\text { businesses } 2015-16\end{array}$ & VIC \\
\hline $\begin{array}{l}\text { Economic Regulation Authority of } \\
\text { Western Australia (annual, latest in } \\
2016 \text { ) }\end{array}$ & $\begin{array}{l}2015 \text { Water, Sewerage and Irrigation } \\
\text { Performance Report }\end{array}$ & WA \\
\hline \multicolumn{3}{|l|}{ Ad hoc reports } \\
\hline Economic insights (2014) & Victorian urban water utility benchmarking & VIC \\
\hline $\begin{array}{l}\text { Essential Services Commission of } \\
\text { Victoria (2012) }\end{array}$ & $\begin{array}{l}\text { An analysis of the productivity of the } \\
\text { Victorian water industry }\end{array}$ & VIC \\
\hline KPMG advisory report (2015) & SA Water Cost Benchmarking & SA \\
\hline
\end{tabular}

\section{Global benchmarking frameworks and practices}

\section{International frameworks}

There is an extensive international literature on performance indicators in relation to water and wastewater services. The International Water Association (IWA) in particular has been prolific in publishing water and wastewater research. This includes two editions (viz. in 2000 and 2006) of Performance Indicators for Water Supply Services: Manual for Best Practice (hereafter referred as IWA 2006 Manual) (Alegre et al., 2000, 2006). These are excellent reference works on performance indicators for water and wastewater services, and present 170 indicators covering six categories, which were developed in consultation with international managers, practitioners and academic researchers (Nürnberg, 2001). The manual provides a large number of examples of indicators and how to calculate 
them. Countries such as Germany and Austria have adopted the benchmarking process described in this manual (Theuretzbacher-Fritz et al., 2005).

As Haider et al. (2014) explain the IWA manual presents a balanced and comprehensive benchmarking system that covers all aspects of water supply services. Its six categories of indicators are further divided into 43 subgroups to enhance understanding of the system. The manual acknowledges the system provides too many performance indicators for most situations, in which some might be considered irrelevant. Thus, Alegre et al. (2006) recommend careful selection of indicators that best fit the user's needs.

Another notable benchmarking publication from IWA includes Performance Indicators for Wastewater Services by Matos et al. (2003), which serves as a manual for benchmarking in wastewater services. It adapts many of the aspects used for water services presented in Alegre et al. (2000) while also reflecting the specific nature of the wastewater business where appropriate. Nevertheless, the 182 performance indicators that it identifies for wastewater services are categorised into the same six groups that Alegre et al. (2000) use for water services.

Cabrera et al. (2011) built upon Alegre et al. (2006) to provide a more practitioner-friendly application manual, while Rathor et al. (2014) present the application of Alegre et al. (2006) using 89 indicators for ten US drinking water supply utilities.

The work of Berg (2010) on measurement, methodology and performance incentives in water utility benchmarking is worthy of special mention. Unlike previous publications, it does not focus on partial indicators; instead, it covers a broader range of benchmarking methodologies including total productivity techniques. Berg (2010) discusses the advantages and disadvantages of the various methodologies and pays special attention to the choice of appropriate variables.

Another important international initiative on water utility benchmarking is the International Benchmarking Network for Water and Sanitation Utilities (IBNET), launched in 1996 as a part of the World Bank's water and sanitation programme. IBNET was created to provide access to comparative information about different utilities and to promote best practice in water supply and sanitation. IBNET describes 80 indicators grouped into 12 categories. However, it does not include some established indicators used in developed countries. Nevertheless, IBNET has had a successful impact on a range of African and Asian countries and is often recommended for developing countries (Haider et al., 2014). Table 4 lists the groupings of indicators employed by IWA and IBNET; notably, none of the above frameworks address the emerging trend of measuring environmental impacts of water and sewerage business. 
Table 4. Comparison of IW A 2006 Manual and IBNET indicators

\begin{tabular}{lc|lc}
\hline IWA 2006 Manual indicators & $\begin{array}{l}\text { No of subgroups } \\
\text { (and indicators) }\end{array}$ & Category & $\begin{array}{c}\text { No of } \\
\text { Category }\end{array}$ \\
\hline Water resources & $2(4)$ & Process indicators & 19 \\
Personnel & $7(26)$ & Service coverage & 3 \\
Physical & $6(15)$ & Water consumption and production & 11 \\
Operational & $9(44)$ & Non-revenue water & 3 \\
Quality of service & $6(34)$ & Meters & 2 \\
Financial and economic & $13(47)$ & Network performance & 1 \\
& & Operating costs and staff & 12 \\
& & Quality of service & 5 \\
& & Billing and collection & 20 \\
& & Financial performance & 2 \\
& & Assets & 1 \\
\hline Total & & Affordability/purchasing power parity & 1 \\
\hline
\end{tabular}

Regional and national frameworks

Many countries have adopted some form of benchmarking and performance measurement of their water service providers. The sophistication varies from country to country, although nearly all of them use some form of partial productivity measure.

In the US, the American Water Works Association initiated performance evaluation of water utilities in 1995. More recently, it initiated the publication Benchmarking Performance Indicators for Water and Wastewater reports. The 2013 edition (American Water Works Association, 2013) lists 73 indicators grouped into five categories: organisational development, business operations, customer service, water operations and wastewater operations.

In Canada, a National Water and Wastewater Benchmarking Initiative (NWWBI) has been underway for around ten years and involves the participation and collaboration of approximately 40 major water and wastewater utilities (AECON, 2017). The performance indicators used in the reporting are based on a Canadian Standards Association adaptation of the International Organization of Standardization (ISO) guidelines, aimed at improving Canadian water utility services (Canadian Standards Association, 2010). In total, 62 performance indicators are grouped according to three components of the water services supply chain - utility, water distribution system, and water treatment. Indicators are set against 16 specific goals.

Also in Canada, the National Research Council (2009), in combination with the National Round Table on Sustainable Infrastructure prepared amongst other things a model framework for potable water systems with 37 indicators grouped into six categories: public safety, public health, environmental quality, social equity, economy and public security. In their assessment of this framework, Haider et al. (2014) suggest the performance indicators are not comprehensive and are more suitable to asset management at a strategic level.

In the UK, the Office of Water Services (Ofwat, 2013) is responsible for the monitoring and performance assessment of water utilities in England and Wales. The reporting of 14 indicators, grouped into four categories, is required for the ten water authorities privatised in 1989. Moreover, Ofwat calculates 
aggregated measures of customer satisfaction - the Service Intensive Mechanism (SIM) and the Security of Water Supply Index (SoSI). SIM is used to control water rates, whereas SoSI ensures adequate levels of service from the providers.

The Asian Development Bank (2012) developed a set of indicators for its projects in China, including projects in the water supply sector. There are 54 indicators set against eight major project objectives.

The European Benchmarking Co-operation was established by a number of European national water associations and currently covers most countries of Western Europe and some countries in Central and Eastern Europe. As far as possible, it follows the International Water Association (IWA) manuals of best practice (European Benchmarking Co-operation, 2015, 2017).

Similarly, the Arab Countries Water Utilities Association, which covers participants from 17 countries, aligns its performance measurement approach and indicators to the manuals of best practice published by the IWA (Arab Countries Water Utilities Association, 2017).

Haider et al. (2014) provide a useful assessment of major benchmarking systems based on the following criteria: understandability, measurability, comparability, simplicity, comprehensiveness, and applicability to small utilities. Table 5 suggests the IWA Manual for Best Practice (Alegre et al., 2006) provides the best overall approach, at least based on this criteria. By comparison to the framework adopted by Australia's NWC (and more recently, Bureau of Meteorology, 2017) the IWA system scores better in the areas of measurability, comparability, comprehensiveness and applicability to small utilities. A particular criticism of the NWC framework relates to the fact that indicators are presented in raw form rather than in ratios, which limits their value in terms of measurability and comparability. 
Table 5. Evaluation of different performance assessment systems (adapted from Haider et al., 2014, p. 22)

\begin{tabular}{lllllll}
\hline $\begin{array}{l}\text { Performance } \\
\text { assessment } \\
\text { system }\end{array}$ & Understandability & Measurability & Comparability & Simplicity & Comprehensiveness & $\begin{array}{l}\text { Applicability } \\
\text { to small } \\
\text { utilities }\end{array}$ \\
\cline { 2 - 6 } & Medium & Medium & Low & Medium & Medium & Medium \\
\hline WB & Low & Medium & Low & Low & Medium & Low \\
\hline OFWAT & Low & Medium & Medium & Low & Medium & Medium \\
\hline ADB & High & Low & Low & Medium & Medium & Medium \\
\hline NWC & Low & Medium & Low & Medium & Low & Low \\
\hline NRC & Medium & Medium & High & Medium & High & High \\
\hline IWA & Low & Medium & Low & Low & Medium & Low \\
\hline AWWA & Medium & Medium & Medium & Low & Medium & Medium \\
\hline CSA & & & & &
\end{tabular}

Note: WB - World Bank (van den Berg and Danilenko, 2011); OFWAT (Office of Water Services for England and Wales, 2013); ADB (Asian Development Bank, 2012); NWC - National Water Commission (Bureau of Meteorology, 2017); NRC (National Research Council, 2009); IWA - International Water Association (Alegre et al., 2006); AWWA (American Water Works Association, 2013); CSA (Canadian Standards Association, 2010).

\section{Overview of Australian academic research on performance measurement}

Australian academic research on performance measurement of water utilities had been practically nonexistent until the National Water Initiative in 2004. The initiative brought about a uniform reporting standard for major utilities. Initially, the dearth of comparable information had been the result of a lack of focus, and subsequently, was a consequence of a lack of suitable data on which to conduct analytical research.

The earliest relevant article was published in 2004 by Woodbury and Dollery (2004). It was focused on NSW water suppliers and used data from 1998 to 2000. It employed methodologies popular in operational research in the form of DEA for cross-utility efficiency comparisons, and the Malmquist total factor productivity (TFP) index for measuring technological change, as well as changes in technical and scale efficiencies. The article by Woodbury and Dollery (2004) reported sizeable technical inefficiencies in water service providers and small positive changes in TFP over the two-year period concerned.

The following year, an article by Coelli and Walding (2005) analysed 18 major Australian utilities over a seven-year period from 1996-2003. This article employed DEA and Malmquist TFP approaches and reported an average technical efficiency for utilities of $90 \%$ with small changes (negative and positive for individual utilities) in TFP over the period.

Byrnes et al. (2010) used DEA to analyse Victorian and NSW water utilities from 2000-2004. They found substantial technical inefficiencies but high levels of scale efficiencies. In addition, in the dataset they identified a number of factors that affected technical efficiency including water conservation measures, droughts, the proportion of industrial customers and variant sources of water. 
More recent publications have used data from the NPR. Worthington $(2011,2014)$ analysed 55 major Australian utilities for the period 2006-2009 using the Malmquist TFP index and DEA and found Australian utilities exhibited small productivity growth attributable equally to technical and scale efficiency improvements with practically no technological change. Using DEA, he found that Australian utilities showed high levels of operational and capital efficiencies.

Finally, Cunningham (2013) used a similar data set with a clear focus on examining and comparing Victoria's utilities with those of the rest of Australia. Using TFP and SFA methods in the analysis, the article found high levels of productivity in Victorian utilities.

In summary, Australian academic research has been limited by data constraints until 2004. Over a tenyear period, only six academic papers focusing on performance measurement in the industry were published. They all employed a total, frontier-based methodology with DEA being the method of choice for cross-utility comparisons and the Malmquist index providing the primary method of measuring productivity changes over time. The Australian academic literature is summarised in Table 6.

Table 6. Academic research on water utility performance measurement in Australia

\begin{tabular}{|c|c|c|c|}
\hline Author(s) & Data set & Method(s) & Main findings \\
\hline $\begin{array}{l}\text { Woodbury and } \\
\text { Dollery (2004) }\end{array}$ & $\begin{array}{l}73 \text { water suppliers in } \\
\text { New South Wales, } \\
1997 / 98-1999 / 2000\end{array}$ & $\begin{array}{l}\text { DEA, } \\
\text { Malmquist } \\
\text { TFP index }\end{array}$ & $\begin{array}{l}\text { Technical inefficiency is larger than } \\
\text { scale inefficiency. Slight increase in } \\
\text { TFP over } 2 \text { years. }\end{array}$ \\
\hline $\begin{array}{l}\text { Coelli and } \\
\text { Walding } \\
\text { (2005) }\end{array}$ & $\begin{array}{l}18 \text { Australian water } \\
\text { services businesses, } \\
1995 / 96 \text { to } 2002 / 03\end{array}$ & $\begin{array}{l}\text { DEA, } \\
\text { Malmquist } \\
\text { TFP index }\end{array}$ & $\begin{array}{l}\text { Average technical efficiency is } 90 \% \text {, } \\
\text { annual TFP growth between }-1.7 \% \text { and } \\
1.1 \% \text {. The study highlighted problems } \\
\text { with the data. }\end{array}$ \\
\hline $\begin{array}{l}\text { Byrnes et al. } \\
(2010)\end{array}$ & $\begin{array}{l}14 \text { Victoria and } 38 \text { NSW } \\
\text { water utilities, 2000-04 }\end{array}$ & DEA & $\begin{array}{l}\text { Substantial room for improvement for } \\
\text { technical efficiency; high scale } \\
\text { efficiency. Water conservation, } \\
\text { droughts \& large numbers of industrial } \\
\text { customers reduce efficiency; } \\
\text { groundwater is source of efficiency in } \\
\text { NSW. }\end{array}$ \\
\hline $\begin{array}{l}\text { Worthington } \\
\text { (2011) }\end{array}$ & $\begin{array}{l}55 \text { major Australian } \\
\text { water utilities, 2006-09 }\end{array}$ & $\begin{array}{l}\text { Malmquist } \\
\text { index }\end{array}$ & $\begin{array}{l}\text { Productivity growth averaged } 1.04 \% \\
\text { with equal shares of technical and } \\
\text { scale efficiency improvements. } \\
\text { Technological improvement is very } \\
\text { small. Environmental factors explain } \\
\text { only small proportion of TFP variation. }\end{array}$ \\
\hline $\begin{array}{l}\text { Cunningham } \\
\text { (2013) }\end{array}$ & $\begin{array}{l}54 \text { major Australian } \\
\text { water utilities (mostly } \\
\text { from Victoria), 1998- } \\
2010 \text { for large utilities, } \\
2006-10 \text { for smaller } \\
\text { utilities }\end{array}$ & TFP, SFA & $\begin{array}{l}\text { Productivity has declined } 2006-10 . \\
\text { Major urban Victorian utilities are more } \\
\text { efficient than others (regional Victorian } \\
\text { and major utilities in other states). }\end{array}$ \\
\hline $\begin{array}{l}\text { Worthington } \\
\text { (2014) }\end{array}$ & $\begin{array}{l}55 \text { major water utilities, } \\
2006-09\end{array}$ & DEA & $\begin{array}{l}\text { High level of operational and capital } \\
\text { efficiency. }\end{array}$ \\
\hline
\end{tabular}




\section{Overview of international academic research on performance measurement}

International academic research directed towards measuring performance of water utilities can be traced at least as far back as the late-1960s. With the development of appropriate statistical methods and general interest in debate of optimal scale of industrial organisation in various heavy industries, published research on performance measurement started to appear, focused mainly on rail transport and electricity companies. However, performance measurement research gradually emerged on water utilities in England and Wales (Ford and Warford, 1969).

The primary methodology of analysis of water utilities was the econometric application of cost functions. Academic research was chiefly directed at identifying economies of scale in the respective industries as well as comparative work on the performance of private versus public enterprise (Abbott and Cohen, 2009). In the 1970s, 1980s and early-1990s research focused almost exclusively on water supply and sewerage providers in the US.

Regression analysis of cost functions continued to be the most widely applied methodology well into the 2000s. However, the type of cost functions and explanatory variables used, as well as their econometric treatment, varied significantly.

From the late-1990s onwards, academic research into performance measurement of water utilities extended beyond the US and UK. Analysis of water utilities was conducted in countries such as Korea (Kim and Lee, 1998), Canada (Renzetti, 1999), Italy (Fabbri and Fraquelli, 2000; Fraquelli and Giandrone, 2003), France (Garcia and Thomas, 2001), Japan (Mizutani and Urakami, 2001), Peru (Corton, 2003), Germany (Sauer, 2005; Sauer and Frohberg, 2007), Portugal (Martins et al., 2006) and Brazil (Nauges and van den Berg, 2007). Abbott and Cohen (2009) provide an extensive list of early international literature.

\section{Data Envelopment Analysis}

With the development of frontier approaches in operations research, it was only a matter of time before the methodology was applied to water utilities. One such method, data envelopment analysis or DEA, was used for the first time in performance measurement of water utilities by Byrnes et al. (1986). They looked at the performance of 68 public and 59 non-public water providers. It took time for the methodology to receive broad acceptance in its application to water utilities as evidenced by the fact that only four articles using the approach were published in the 1990s, focused on the UK and USA (Norman and Stoker, 1991; Lambert et al., 1993; Sawkins and Accam, 1994; Cubbin and Tzanidakis, 1998). The 2000s saw a dramatic rise in the popularity of DEA methodology in a variety of applications, including those focused on performance measurement in water utilities. At least 16 articles were published analysing European, South American, Asian and African water providers. The primary focus of these studies covered a variety of issues, again primarily private versus public ownership, the impact of regulation and the relative efficiency of water service providers. In addition, a number of articles analysed changes in productivity over time (Abbott and Cohen, 2009; Walter et al., 2009). Table 7 
provides an extensive list of the literature that applied DEA to performance measurement of water utilities.

Table 7. International research into water utility performance measurement based on DEA methods

\begin{tabular}{|c|c|c|c|}
\hline Publication & Year & Dataset & Methodology \\
\hline Byrnes et al. (1986) & 1986 & $\begin{array}{l}\text { United States, } 68 \text { government and } 59 \\
\text { private companies, } 1978\end{array}$ & DEA \\
\hline Norman and Stoker (1991) & 1991 & $\begin{array}{l}\text { England and Wales, } 28 \text { water-only } \\
\text { companies, } 1987 / 88\end{array}$ & DEA \\
\hline Lambert et al. (1993) & 1993 & $\begin{array}{l}\text { United States, } 238 \text { public and } 33 \text { private } \\
\text { companies, } 1989\end{array}$ & DEA \\
\hline Sawkins and Accam (1994) & 1994 & $\begin{array}{l}\text { Scotland, } 9 \text { regional and } 3 \text { island councils, } \\
1984 / 85 \text { and } 1992 / 93 /\end{array}$ & DEA \\
\hline $\begin{array}{l}\text { Cubbin and Tzanidakis } \\
(1998)\end{array}$ & 1998 & $\begin{array}{l}\text { England and Wales, } 29 \text { companies, } \\
1992 / 93\end{array}$ & $\begin{array}{l}\text { DEA \& } \\
\text { Stochastic cost }\end{array}$ \\
\hline Thanassoulis (2000) & 2000 & $\begin{array}{l}\text { England and Wales, } 10 \text { water and } \\
\text { sewerage companies, } 1994\end{array}$ & DEA \\
\hline $\begin{array}{l}\text { Anwandter and Ozuna } \\
(2002)\end{array}$ & 2002 & Mexico, 110 utilities, 1995 & DEA \\
\hline Thanassoulis (2002) & 2002 & $\begin{array}{l}\text { England and Wales, } 10 \text { water and } \\
\text { sewerage companies, } 1994\end{array}$ & DEA \\
\hline $\begin{array}{l}\text { Tupper and Resende } \\
\text { (2004) }\end{array}$ & 2004 & $\begin{array}{l}\text { Brazil, } 20 \text { water and sewerage companies, } \\
1996-2000\end{array}$ & DEA \\
\hline García-Sánchez (2006) & 2006 & Spain, 24 towns, 1999 & DEA \\
\hline Hu et al. (2006) & 2006 & China, 30 regions, $1997-2002$ & DEA \\
\hline Kirkpatrick et al. (2006) & 2006 & Africa, 66 firms, 2000 & $\begin{array}{l}\text { DEA \& } \\
\text { Stochastic cost } \\
\text { frontier }\end{array}$ \\
\hline Erbetta and Cave (2007) & 2007 & $\begin{array}{l}\text { England and Wales, } 10 \text { water and } \\
\text { sewerage companies, 1993-2005 }\end{array}$ & DEA, SFA \\
\hline $\begin{array}{l}\text { García-Valiñas and Muñiz } \\
\text { (2007) }\end{array}$ & 2007 & Spain, 3 municipalities, $1985-2000$ & DEA \\
\hline Berg and Lin (2008) & 2008 & Peru, 44 water utilities, 1996-98 & DEA, SFA \\
\hline Picazo-Tadeo et al. (2008) & 2008 & Spain, 40 water utilities & DEA \\
\hline Corton and Berg (2009) & 2009 & Central America, 6 countries & $\begin{array}{l}\text { DEA, TFP } \\
\text { indices \& SFA }\end{array}$ \\
\hline Guder et al. (2009) & 2009 & Germany, 373 water utilities, 2006 & DEA \\
\hline Munisamy (2009) & 2009 & $\begin{array}{l}\text { Malaysia, } 6 \text { water supply authorities and } 11 \\
\text { privatised water companies, } 2005\end{array}$ & DEA \\
\hline $\begin{array}{l}\text { Picazo-Tadeo, Sáez- } \\
\text { Fernández et al. (2009) }\end{array}$ & $2009 a$ & Andalusia, Spain, 34 utilities, 2001 & DEA \\
\hline $\begin{array}{l}\text { Picazo-Tadeo, González- } \\
\text { Gómez et al. (2009) }\end{array}$ & $2009 b$ & Andalusia, Spain, 34 utilities, 2001 & DEA \\
\hline $\begin{array}{l}\text { Renzetti and Dupont } \\
(2009)\end{array}$ & 2009 & Canada, 64 water utilities, 1996 & DEA \\
\hline Singh et al. (2011) & 2011 & North India, 35 urban water utilities & DEA \\
\hline Zschille (2015) & 2015 & Germany, 364 water utilities, 2006 & DEA \\
\hline $\begin{array}{l}\text { Molinos-Senante et al. } \\
(2016)\end{array}$ & 2016 & Chile, 25 largest water utilities, 2013 & DEA \\
\hline $\begin{array}{l}\text { Pointon and Matthews } \\
\text { (2016) }\end{array}$ & 2016 & $\begin{array}{l}\text { England and Wales, } 10 \text { water and } \\
\text { sewerage companies, 1997-2011 }\end{array}$ & Dynamic DEA \\
\hline
\end{tabular}




\section{Stochastic Frontier Analysis}

As with DEA the stochastic frontier analysis (SFA) approach was first applied to water utilities in the 1980 s by Fox and Hofler (1985). They conducted a technical and allocative efficiency estimation of 156 public and 20 private water utilities in the US. In the 1990s only three studies employed the method to analyse the efficiency of water service providers. These studies, by Lynk (1993), Bhattacharyya et al. (1995) and Cubbin and Tzanidakis (1998), focused on UK and US samples. As was the case with DEA, the SFA methodology gained wider recognition and acceptance in the 2000s with nearly a dozen articles presenting their findings on datasets from Asia, Europe, the Americas and Africa. A summary of the literature that employed stochastic frontier approaches is provided in Table 8.

Table 8. International research into water utility performance measurement based on stochastic frontier methods

\begin{tabular}{|c|c|c|c|}
\hline Publication & Year & Dataset & Methodology \\
\hline Fox and Hofler (1985) & 1985 & $\begin{array}{l}\text { USA, } 156 \text { public and } 20 \text { private } \\
\text { utilities }\end{array}$ & $\begin{array}{l}\text { Stochastic frontier } \\
\text { techniques }\end{array}$ \\
\hline Lynk (1993) & 1993 & $\begin{array}{l}\text { England and Wales, } 10 \text { water and } \\
\text { sewerage companies, } 28 \text { water-only } \\
\text { companies, } 1979 / 80-1987 / 88\end{array}$ & $\begin{array}{l}\text { Stochastic cost } \\
\text { functions }\end{array}$ \\
\hline Bhattacharyya et al. (1995) & 1995 & $\begin{array}{l}\text { United States, } 190 \text { public and } 31 \\
\text { private utilities, } 1992\end{array}$ & $\begin{array}{l}\text { Stochastic cost } \\
\text { frontier }\end{array}$ \\
\hline $\begin{array}{l}\text { Cubbin and Tzanidakis } \\
\text { (1998) }\end{array}$ & 1998 & $\begin{array}{l}\text { England and Wales, } 29 \text { companies, } \\
1992 / 93\end{array}$ & $\begin{array}{l}\text { Stochastic cost } \\
\text { function \& DEA }\end{array}$ \\
\hline Estache and Rossi (2002) & 2002 & $\begin{array}{l}\text { Asia Pacific, } 50 \text { water companies in } \\
29 \text { countries, } 22 \text { of which involve } \\
\text { private participation, } 1995\end{array}$ & $\begin{array}{l}\text { Stochastic cost } \\
\text { frontier }\end{array}$ \\
\hline Bottasso and Conti (2003) & 2003 & $\begin{array}{l}\text { England and Wales, } 10 \text { water and } \\
\text { sewerage companies, } 12 \text { water-only } \\
\text { companies, } 1995-2001\end{array}$ & $\begin{array}{l}\text { Stochastic variable } \\
\text { cost frontier }\end{array}$ \\
\hline Aubert and Reynaud (2005) & 2005 & Wisconsin, 211 utilities, $1998-2000$ & $\begin{array}{l}\text { Stochastic cost } \\
\text { frontier }\end{array}$ \\
\hline Fraquelli and Moiso (2005) & 2005 & Italy, 18 regions, 30 years & $\begin{array}{l}\text { Stochastic cost } \\
\text { frontier, translog }\end{array}$ \\
\hline Kirkpatrick et al. (2006) & 2006 & Africa, 66 firms, 2000 & $\begin{array}{l}\text { Stochastic cost } \\
\text { frontier and DEA }\end{array}$ \\
\hline $\begin{array}{l}\text { da Silva e Souza et al. } \\
\text { (2007) }\end{array}$ & 2007 & $\begin{array}{l}\text { Brazil, } 149 \text { public and } 15 \text { private } \\
\text { companies, } 2002\end{array}$ & $\begin{array}{l}\text { Stochastic frontier } \\
\text { techniques }\end{array}$ \\
\hline Mugisha (2007) & 2007 & Uganda, water utilities, 1996-2004 & $\begin{array}{l}\text { Stochastic frontier } \\
\text { analysis }\end{array}$ \\
\hline Saal et al. (2007) & 2007 & $\begin{array}{l}\text { England and Wales, } 10 \text { water and } \\
\text { sewerage companies, } 1985-2000\end{array}$ & $\begin{array}{l}\text { Stochastic frontier } \\
\text { techniques }\end{array}$ \\
\hline Berg and Lin (2008) & 2008 & Peru, 44 water utilities, 1996-98 & $\begin{array}{l}\text { Stochastic frontier } \\
\text { analysis \& DEA }\end{array}$ \\
\hline Corton and Berg (2009) & 2009 & Central America, 6 countries & $\begin{array}{l}\text { Stochastic frontier } \\
\text { analysis, TFP indices } \\
\text { \& DEA }\end{array}$ \\
\hline Horn (2011) & 2011 & Japan, 392 water utilities, 2005 & $\begin{array}{l}\text { Stochastic cost } \\
\text { frontier }\end{array}$ \\
\hline
\end{tabular}

\section{Other methods}

The application of other methods of performance measurement in the academic literature has been scarce. A few articles have used partial productivity measures in the form of financial and operational ratios, notably Sawkins (1996), Shaoul (1997), Helland and Adamsson (1998), Marques and Monteiro 
(2001), and Kanakoudis and Tsitsifli (2010). There have also been some articles that presented nonfrontier econometric methods of estimating the productivity of water utilities, including Estache and Kouassi (2002) and Coulibalya and Rodriguez (2004).

One article focused solely on total factor productivity (TFP) indices: Bosworth and Stoneman (1998). And as mentioned earlier, Corton and Berg (2009) employed a TFP methodology alongside DEA and SFA approaches. Table 9 summarises this residual research.

Table 9. Other international water utility performance measurement literature

\begin{tabular}{lcll}
\hline Publication & Year & Dataset & Methodology \\
\hline Sawkins (1996) & 1996 & $\begin{array}{l}\text { England and Wales, 10 water and } \\
\text { sewerage companies, 1989-1994 }\end{array}$ & Financial data \\
\hline Shaoul (1997) & 1997 & $\begin{array}{l}\text { England and Wales, 10 water and } \\
\text { sewerage companies, 1985-1995 }\end{array}$ & $\begin{array}{l}\text { Cost and financial } \\
\text { ratios }\end{array}$ \\
\hline $\begin{array}{l}\text { Bosworth and Stoneman } \\
\text { (1998) }\end{array}$ & 1998 & $\begin{array}{l}\text { England \& Wales, 10 water and } \\
\text { sewerage companies, 1979-89 } \\
\text { and1989-95 }\end{array}$ & TFP index \\
$\begin{array}{l}\text { Helland and Adamsson } \\
\text { (1998) }\end{array}$ & 1998 & $\begin{array}{l}\text { Scandinavia, cities of } \\
\text { Copenhagen, Oslo, Helsinki, } \\
\text { Stockholm, Gothenburg and } \\
\text { Malmo }\end{array}$ & $\begin{array}{l}\text { Partial productivity } \\
\text { indicators }\end{array}$ \\
\hline $\begin{array}{l}\text { Marques and Monteiro } \\
\text { (2001) }\end{array}$ & 2001 & Portugal & $\begin{array}{l}\text { Partial productivity } \\
\text { indicators }\end{array}$ \\
\hline $\begin{array}{l}\text { Estache and Kouassi } \\
\text { (2002) }\end{array}$ & 2002 & Africa, 21 water utilities,1995-97 & $\begin{array}{l}\text { Within-group } \\
\text { estimator, GLS, GMM } \\
\text { and instrumental } \\
\text { variables. }\end{array}$ \\
\hline $\begin{array}{l}\text { Coulibalya and Rodriguez } \\
\text { (2004) }\end{array}$ & 2004 & Quebec, 10 small water utilities & $\begin{array}{l}\text { Aggregate index } \\
\text { Filippini et al. (2008) }\end{array}$ \\
$\begin{array}{l}\text { Kanakoudis and Tsitsifli } \\
\text { (2010) }\end{array}$ & 2008 & Slovenia, 52 water utilities, 1997- & $\begin{array}{l}\text { Pooled OLS, RE, true } \\
\text { fixed effects }\end{array}$ \\
\hline
\end{tabular}

Tables 7-9 highlight an abundance of international academic literature analysing the performance of water utilities over the past 20 years. The literature has mostly focused on three core issues: economies of scale, private versus public ownership, and the impact of various forms of regulation. A comparative analysis of the providers in terms of their productivity and efficiency was not, in most cases, the nucleus of the analysis.

In earlier years, 1970-1990, the vast majority of articles employed some form of econometric treatment of cost functions. The situation has changed since 2000 when total productivity methods such as nonparametric DEA and parametric SFA gained momentum. DEA in particular has been used extensively used, primarily because of its flexibility when functional form does not have to be specified.

\section{Conclusions and policy implications}

This article has provided an expansive review of existing literature regarding benchmarking and performance measurement for water utilities. The review of current Australian practices at the national and state levels revealed the following findings. Performance measurement and reporting in Australia is largely centred around the NWC framework. In some states and territories it is the water utilities that 
collect data for the NWC framework and the relevant jurisdictional government does not collect any other data. This is primarily due to the fact that large sophisticated water utilities cover the vast majority of jurisdictional water utility services (viz. ACT, Tasmania and Victoria). In other states with combinations of sophisticated large utilities, and regional and remote water service providers, data for smaller providers are either limited or not collected at all. Two states that collect data and derive performance measures separately, including for many of the smaller water service providers are NSW and Queensland. The range of indicators in those states partially overlaps with the NWC framework but also have their own state specific estimates and objectives

The NWC framework is found to be strong in a number of areas including understandability and coverage of environmental and financial indicators. Conversely, a clear weakness is the fact that most of the indicators reported are raw data, which limits comparability.

Taking into account the importance of NWC framework for Australia as well as identified weaknesses, in our view it is appropriate to re-visit the NWC framework to address these shortcomings. A review taskforce might develop a lighter framework that would address performance measurement in smaller utilities, including unique rural, remote and remote-indigenous water service providers. There is a considerable wealth of knowledge generated around the globe, and much of the overseas experiences can be tailored for the Australian context.

The second major finding of this review is a considerable gap exists between current industry practice and advances in performance measurement methodologies actively being pursued in the academic literature. Despite the fact that most of the academic literature has latterly been using total methods of performance measurement, industry practice remains deeply entrenched in the application of partial indicators. Those industry reports that do use total methods seem to be entirely ad hoc in nature. There are a number of reasons for this. First, individual partial indicators typically rely on a small number of data items. They are flexible in their application and for most of the data collected there is some indicator or indicators that can be calculated. Second, the calculation of partial performance indicators is easy. Third, partial indicators are readily comprehendible and comparable. Fourth, there is a great variety of indicators that can be associated with given types of performance measurement. Conversely, total methods are undoubtedly more difficult to produce. They depend on more data, all of which should be accurate and consistent. They are more complex in their application and require more specific expertise to produce and interpret. They are also rely on a careful selection of relevant inputs and outputs (as Appendix I highlights). However, the problem with partial methods is that, individually, they only target certain aspects of the water utility business and have to be analysed jointly for a broader view. In the frequent case of conflicting results from a variety of such indicators, it is hard to reconcile them into one holistic picture. Aggregated indices are sometimes constructed to overcome this problem, but indices constructed from partial indicators suffer from the very problems that discourage the use of total methods, and in any event are arbitrary. Above all, they are less fundamentally sound. 
Therefore, the implementation of one or more total methods is warranted when the task is to provide a holistic picture of utility performance. In recent years, frontier methods seem to have dominated the academic landscape. DEA appears to be the method of choice because of its flexibility, as specification of parametric form is not required. However, SFA can also be applied to test the findings of DEA, and total factor productivity methods can be applied for temporal analysis. 


\section{Appendix 1. Brief introduction to total productivity methods: Data Envelopment Analysis and Stochastic Frontier Analysis}

Farrell (1957) illustrated the concept of productive efficiency using a simple isoquant diagram under the assumption of constant returns for a two inputs, single output firm and provides the clearest example of productive efficiency analysis. Figure A1 illustrates the principle using Capital and Opex as inputs of a Water Utility, and water supply as an output:

Figure A1. Production frontier

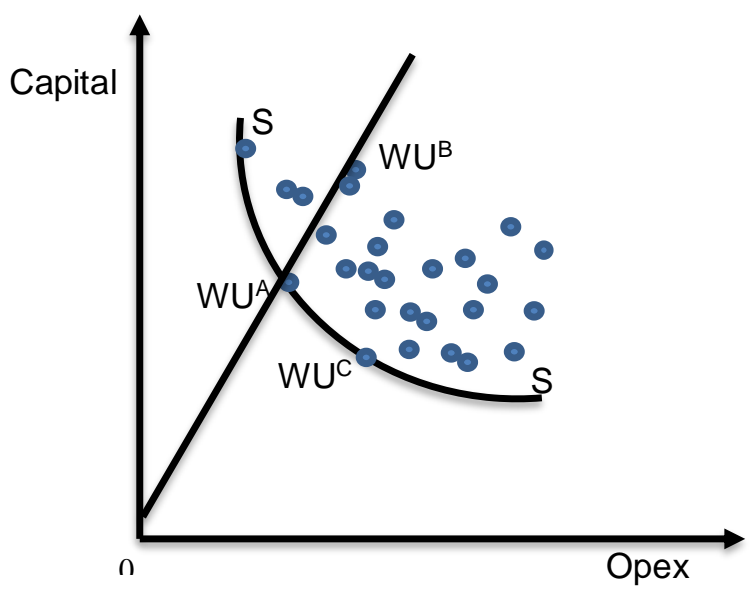

Figure A1 presents the quantities of Capital and Opex used by 27 Water Utilities to produce a single unit of output. Three Water Utilities in particular are highlighted (i.e $W^{A}, W U^{B}$ and $W U^{C}$ ). The isoquant SS essentially forms the efficient frontier of the various possible combinations of Capital and Opex to produce a single unit of output. Note that both Water Utility $A$ and Water Utility $C$ lie on the isoquant SS, albeit with varying combinations of inputs for a given unit of output. Both Utility $A$ and $C$ have efficiency scores of 1. Water Utility B is using inputs in the same proportions as Water Utility A, but Water Utility $B$ does not lie on the efficient frontier. The level of inefficiency of Water Utility $B$ is represented by the distance $\left[W^{A}-W U^{B}\right]$. Conversely, for the same level of inputs as Water Utility $B$, Water Utility $A$ can produce $W U^{B} M U^{A}$ units of output. Productive efficiency of Water Utility $B$ can thus be defined as $W U^{A}$ $/ W U^{B}$. Because the isoquant $S S$ has a negative slope any increase in inputs while holding output constant will always result in a lower efficiency score.

Data Envelopment Analysis (DEA) is a non-parametric linear programming method used to develop production frontiers and undertake comparative analysis of the productive efficiency of various firms. The efficient firms at the extremes of any DEA form a 'best practice' frontier. Firms are then compared against those that set the best-practice frontier; viz. the method assumes that if Water Utility A can produce a given level of outputs for $Y$ inputs, then Water Utility B of similar scale should be capable of producing the same level of output with a similar level of inputs. Any Water Utility not on the bestpractice frontier is considered inefficient. Once Water Utility efficiency has been calculated it is graded 
on a scale from $0-1$, where a score of 1 indicates Water Utility $A$ lies on the efficient frontier. If Water Utility $B$ has a score of 0.5 , it is effectively $50 \%$ less efficient than Water Utility A, i.e. it produces the same amount of output as Water Utility A, but uses twice the amount of inputs. All firms evaluated can then consequently be ranked, based on their calculated efficiency scores. A variable return to scale can also be considered in the model, allowing for the concept of either increasing or decreasing efficiency, based on the company's size and the magnitude of its outputs. An input oriented DEA Problem can be specified as:

$$
\begin{gathered}
\text { Min } \theta, \lambda \theta \\
\text { St } \quad y_{i}+Y \lambda \geq 0, \\
\theta x_{i}-X \lambda \geq 0, \\
\lambda \geq 0 .
\end{gathered}
$$

Where $\theta$ is a scaler and $\lambda$ is a $I x 1$ vector of constants. The value of $\theta$ obtained is the efficiency score for the $i^{\text {th }}$ Water Utility and returns the amount which the $i^{\text {th }}$ Water Utility can reduce inputs holding the level of output constant. This satisfies $\theta \leq 1$, therefore a value of 1.0 represents a point that lies on the best-practice or efficient frontier, and hence represents a Water Utility which is, in comparative terms, characterized by productive efficiency. An output-oriented equivalent of the above problem would benchmark firms against 'best-practice' firms maximising the output given the level of inputs.

Figure A2 provides an indicative example if constructing an efficiency frontier using the SWIMS Queensland Water Utilities dataset, for utilities with more than 50,000 connections.

Figure A2. Production frontier for Queensland water utilities (Connections $>50,000$ )

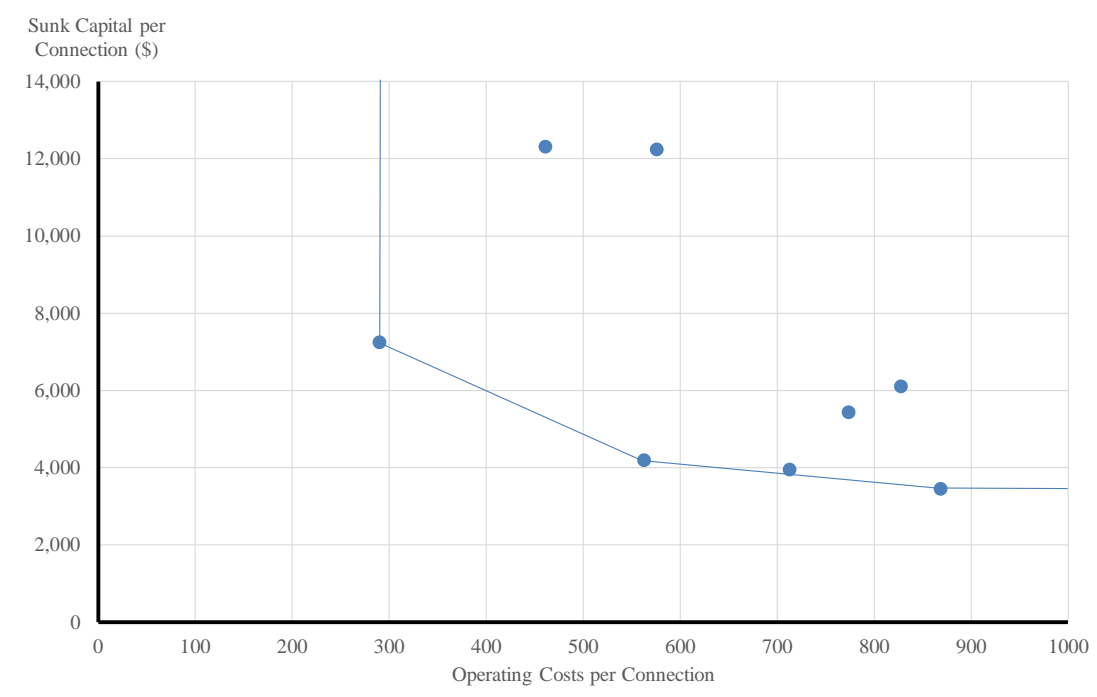

In contrast to DEA, stochastics frontier analysis (SFA) is a parametric method. The frontier is produced deterministically. The SFA method was originated by Aigner, Lovell and Schmidt (1977) and Meeusen and van den Broeck (1977). The production function model is specified as: 
$\ln q_{i}=\mathrm{X}_{i}^{\prime} \beta+v_{i}-u_{i}$

where

- $q_{i}$ is output of the $i$-th firm;

- $\mathrm{X}_{i}$ is $\mathrm{K} \times 1$ vector of input quantities of the $i$-th firm;

- $\quad \beta$ is a vector of unknown parameters;

- $\quad v_{i}$ is a symmetric random error to account for statistical noise; and

- $u_{i}$ is a non-negative random variable representing technical efficiency.

Assuming for simplicity a one input- one output model, a Cobb-Douglas Stochastic Frontier Model is specified:

$q_{i}=\exp \left(\beta_{0}+\beta_{1} \ln x_{i}\right) \times \exp \left(v_{i}\right) \times \exp \left(u_{i}\right)$

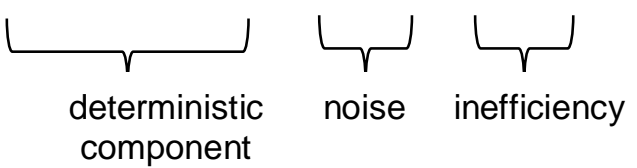

A simple example of hypothetical water utilities with one input (viz. total expenses) and one output (water supplied) is presented in Figure A3. Water Utility A's total expenses $x_{A}$ are used to supply $q_{A}$ of water. If there were no inefficiency effect, then so-called frontier output would be

$\dot{q}_{A}=\exp \left(\beta_{0}+\beta_{1} \ln x_{A}+v_{A}\right)$.

In this example, output for Water Utility A lies below the deterministic component of the frontier because of the negative noise effect (in this case $u_{A}<0$ ).

Figure A3. Stochastic frontier for a hypothetical water utility

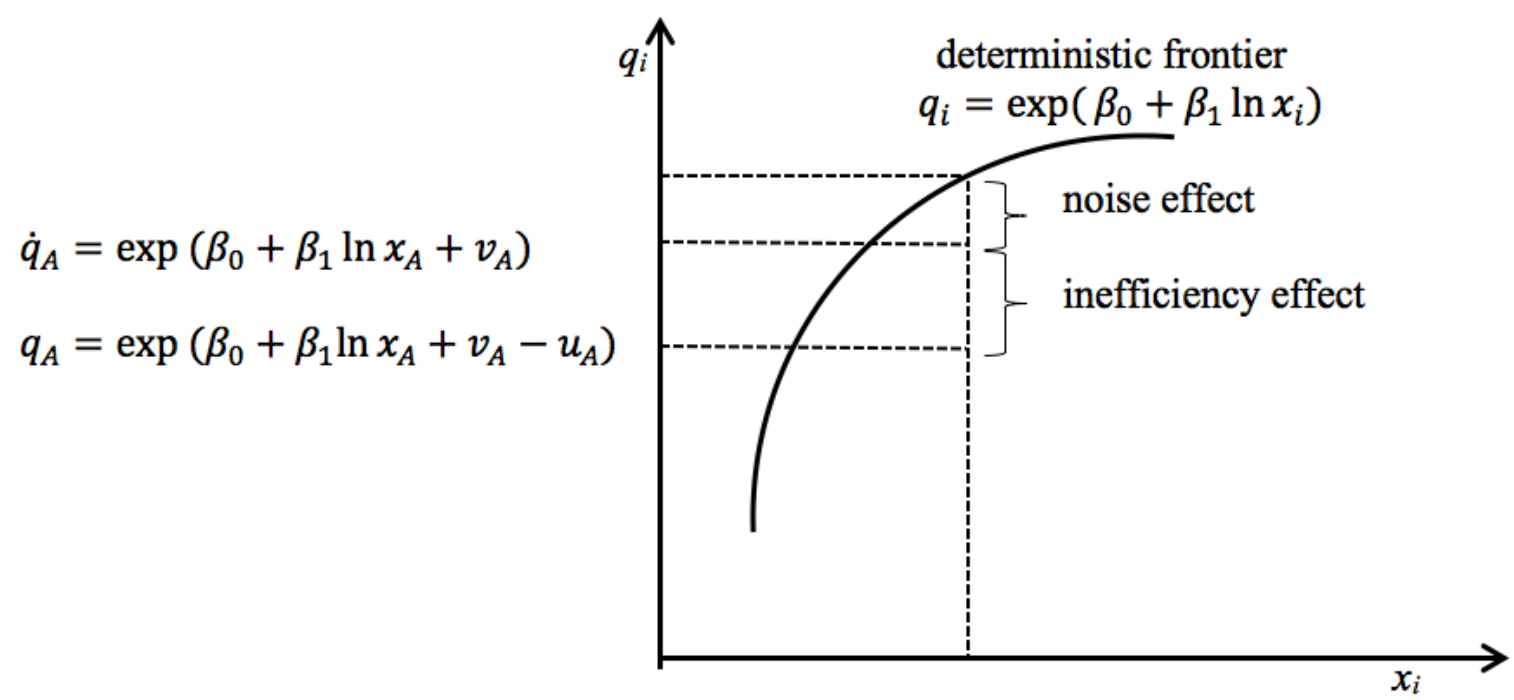




\section{References}

Abbott, M. \& Cohen, B. 2009, 'Productivity and efficiency in the water industry', Utilities Policy, vol. 17, no. 3-4, pp. 233-244.

ACIL Tasman 2005, Institutional arrangements in the Australian water sector: Information Paper. Preepared for National Water Commission., ACIL Tasman, Melbourne.

AECON 2017, National Water and Wastewater Benchmarking Initiative: Tables of Water Performance Measures National Water and Wastewater Benchmarking Initiative, Burnaby.

Alegre, H., Baptista, J.M., Cabrera, E.J., Cubillo, F., Duarte, P., Hirner, W., Merkel, W. \& Parena, R. 2006, Performance indicators for water supply services. Manual for best practice, International Water Association, London.

Alegre, H., Hirner, W., Baptista, J.M. \& Parena, R. 2000, Performance indicators for water supply services. Manual for best practice, International Water Association, London.

American Water Works Association 2013, Benchmarking. Performance indicators for water and wastewater: 2013 survey data and analyses report, American Water Works Association, Denver.

Anwandter, L. \& Ozuna, T., Jr. 2002, 'Can public sector reforms improve the efficiency of public water utilities?', Environment and Development Economics, vol. 7, no. 4, pp. 687-700.

Arab Countries Water Utilities Association 2017, 'Training course for senior managers on performance indicators and benchmarking for water utilities in the Arab region'. Retrieved 10 August 2017 from

https://acwua.org/library/acwua-publications/145-training-course-for-senior-managers-onperformance-indicators-and-benchmarking-for-water-utilities-in-the-arab-region

Asian Development Bank 2012, Handbook for selecting performance indicators for ADB-funded projects in PRC, Asian Development Bank, Manilla.

Aubert, C. \& Reynaud, A. 2005, 'The impact of regulation on cost efficiency: An empirical analysis of Wisconsin water utilities', Journal of Productivity Analysis, vol. 23, no. 3, pp. 383-409.

Berg, S. \& Lin, C. 2008, 'Consistency in performance rankings: the Peru water sector', Applied Economics, vol. 40, no. 6, pp. 793-805.

Berg, S.V. 2010, Water Utility Benchmarking: Measurement, Methodologies, and Performance Incentives, IWA Publishing, London.

Bhattacharyya, A., Harris, T., Narayanan, R. \& Raffiee, K. 1995, 'Specification and estimation of the effect of ownership on the economic efficiency of the water utilities', Regional Science and Urban Economics, vol. 25, no. 6, pp. 759-784.

Bosworth, D. \& Stoneman, P. 1998, 'An efficiency study for the water industry'. Final report: A report to National Economic Research Associates, London. 
Bottasso, A. \& Conti, M. 2003, Cost Inefficiency in the English and Welsh Water Industry: an Heteroskedastic Stochastic Cost Frontier Approach, DIEM.

Bureau of Meteorology 2017, National performance report 2015-16: Urban water utilities, Part A, Bureau of Meteorology, Melbourne.

Byrnes, J., Crase, L., Dollery, B. \& Villano, R. 2010, 'The relative economic efficiency of urban water utilities in regional New South Wales and Victoria', Resource and Energy Economics, vol. 32, no. 3, pp. 439-455.

Byrnes, P., Grosskopf, S. \& Hayes, K. 1986, 'Efficiency and ownership: Further evidence', The Review of Economics and Statistics, vol. 68, no. 2, pp. 337-341.

Cabrera, E., Dane, P., Haskins, S. \& Theuretzbacher-Fritz, H. 2011, Benchmarking Water Services. Guiding water utilities to excellence, American Water Works Association and International Water Association, Denver.

Canadian Standards Association 2010, Activities relating to drinking water and wastewater services. Guidelines for the management of the drinking water utilities and for the assessment of drinking water services, \# CAN/CSA-Z24512-10, Standards Council of Canada and Canadian Standards Association, Ottawa.

Coelli, T. \& Walding, S. 2005, Performance measurement in the Australian water supply industry, Centre for Efficiency and Productivity Analysis, Brisbane.

Corton, M.L. 2003, 'Benchmarking in the Latin American water sector: The case of Peru', Utilities Policy, vol. 11 , no. 3, pp. 133-142.

Corton, M.L. \& Berg, S.V. 2009, 'Benchmarking Central American water utilities', Utilities Policy, vol. 17, no. 3, pp. 267-275.

Coulibalya, H.D. \& Rodriguez, M.J. 2004, 'Development of performance indicators for small Quebec drinking water utilities', Journal of environmental management, vol. 73, pp. 243-255.

Council of Australian Governments 1994, 'Attachment A - Water Resource Policy'. Retrieved 10 March 2017

from

http://webarchive.nla.gov.au/gov/20150301030733/http://archive.coag.gov.au/coag_meeting_outcome s/1994-02-25/docs/attachment_a.cfm

Council of Australian Governments 2004, 'Intergovernmental Agreement on a National Water Initiative'. Retrieved 10 March 2017 from http://www.agriculture.gov.au/water/policy/nwi

Cubbin, J. \& Tzanidakis, G. 1998, 'Regression versus data envelopment analysis for efficiency measurement: An application to the England and Wales regulated water industry', Utilities Policy, vol. 7, no. 2, pp. 75-85.

Cunningham, M.B. 2013, 'Productivity Benchmarking the Australian Water Utilities', Economic Papers: A journal of applied economics and policy, vol. 32, no. 2, pp. 174-189. 
da Silva e Souza, G., Coelho de Faria, R. \& Belchiar S Moreira, T. 2007, 'Estimating the relative efficiency of Brazilian publicly and privately owned water utilities: a stochastic cost frontier approach', Journal of the American Water Resources Association, vol. 43, no. 5, pp. 1237-1244.

de Melo Baptista, J.F. (ed) 2014, The Regulation of Water and Waste Services. An Intergrated Approach, IWA Publishing, London.

Department of Agriculture and Water Resources 2017, 'National Water Initiative'. Retrieved 10 March 2017 from http://www.agriculture.gov.au/water/policy/nwi

Department of the Environment and Energy 2017, National greenhouse accounts factors, Department of the Environment and Energy, Australian Government, Canberra.

Dollery, B., \& Akimov, A. (2008). A Critical Comment on the Analysis of Shared Services in the Queensland Local Government Association's Size, Shape and Sustainability Program. Accounting, Accountability and Performance, vol. 14, no. 2, pp. 29-44.

Dollery, B., Wallis, J., \& Akimov, A. (2010). One Size Does Not Fit All: The Special Case of Remote Small Local Councils in Outback Queensland. Local Government Studies, vol. 36, no. 1, pp. 21-42.

Economic Insights 2014, 'Victorian Urban Water Utility Benchmarking'. Report prepared for the Essential Services Commission. Economic Insights, Eden, NSW.

ERA: Economic Regulation Authority of Western Australia 2016, 2015 Water, Sewerage and Irrigation Performance Report, Economic Regulation Authority of Western Australia, Perth.

Erbetta, F. \& Cave, M. 2007, 'Regulation and efficiency incentives: Evidence from the England and Wales water and sewerage industry', Review of Network Economics, vol. 6, no. 4, pp. 425-452

ESC: Essential Service Commission Victoria 2012, An analysis of the productivity of the Victorian water industry, Staff Research Paper No. 12/1, http://www.esc.vic.gov.au/.

ESC: Essential Service Commission Victoria 2015, The productivity of the Victoria's water industry, Staff Paper, http://www.esc.vic.gov.aul.

ESC: Essential Services Comission of Victoria 2016, Water Performance Report. Performance of Victorian urban water and sewerage businesses 2015-16. Essential Services Comission of Victoria, Melbourne.

ESCOSA: Essential Services Commission of South Australia 2016, Minor and Intermediate Retailers Regulatory Performance Report 2014-15, Essential Services Commission of South Australia, Adelaide. ESCOSA: Essential Services Commission of South Australia 2017, SA Water Regulatory Performance Report 2015-16, Essential Services Commission of South Australia, Adelaide.

Estache, A. \& Kouassi, E. 2002, Sector organization, governance, and the inefficiency of African water utilities, Washington DC.

Estache, A. \& Rossi, M.A. 2002, 'How different is the efficiency of public and private water companies in Asia?', The World Bank Economic Review, vol. 16, no. 1, pp. 139-148. 
European Benchmarking Co-operation 2015, Learning from international best practices, European Benchmarking Co-operation, www.waterbenchmark.org.

European Benchmarking Co-operation 2017, 'Benchmarking programmes'. Retrieved 10 August 2017 from www.waterbenchmark.org

Fabbri, P. \& Fraquelli, G. 2000, 'Costs and structure of technology in the Italian water industry', Empirica, vol. 27 , pp. 65-82.

Filippini, M., Hrovatin, N. \& Zorić, J. 2008, 'Cost efficiency of Slovenian water distribution utilities: an application of stochastic frontier methods', Journal of Productivity Analysis, vol. 29, no. 2, pp. 169-182.

Ford, J. \& Warford, J. 1969, 'Cost functions for the water industry', Journal of Industrial Economics, vol. 18, no. 1 , pp. 53-63.

Fox, W. \& Hofler, R. 1985, 'Using homothetic composed error frontiers to measure water utility efficiency', Southern Economic Journal, vol. 53, no. 2, pp. 461-477.

Fraquelli, G. \& Giandrone, R. 2003, 'Reforming the wastewater treatment sector in Italy: implications of plant size, structure and scale economies', Water Resources Research, vol. 39, no. 10, pp. 1293-1301.

Fraquelli, G. \& Moiso, V. 2005, Cost Efficiency and Economies of Scale in the Italian Water Industry, SIEP.

Garcia-Valiñas, M.A. \& Muñiz, M.A. 2007, 'Is DEA useful in the regulation of water utilities? A dynamic efficiency evaluation (a dynamic efficiency evaluation of water utilities)', Applied Economics, vol. 39, no. 2, pp. 245-252.

García-Sánchez, I.M. 2006, 'Efficiency measurement in Spanish local government: The case of municipal water services', Review of Policy Research, vol. 23, no. 2, pp. 355-372.

Garcia, S., Moreaux, M. \& Reynaud, A. 2007, 'Measuring economies of vertical integration in network industries: An application to the water sector', International Journal of Industrial Organization, vol. 25, no. 4, pp. 791-820.

Guder, J., Kittlau, B., Moll, R., Walter, M. \& Zschille, M. 2009, The performance of German water utilities: A first non-parametric analysis, DIW Berlin (German Institute for Economic Research) and Dresden University of Technology Efficiency Analysis.

Haider, H., Sadiq, R. \& Tesfmariam, S. 2014, 'Performance indicators for small- and medium-sized water supply systems: a review', Environmental Review, vol. 22, no. 1, pp. 1-40.

Helland, B. \& Adamsson, J. 1998, 'Performance indicators: benchmarking between six cities in Scandinavia', Aqua, vol. 47, no. 6, pp. 284-288.

Horn, T. 2011, 'Incorporating water purification in efficiency evaluation: Evidence from Japanese water utilities', Applied Economics Letters, vol. 18, no. 18, pp. 1789-1794.

Hu, J.-L., Wang, S.-C. \& Yeh, F.-Y. 2006, 'Total-factor water efficiency of regions in China', Resources Policy, vol. 31, no. 4, pp. 217-230. 
Icon Water Limited 2016a, Annual Drinking Water Quality Report 2015-16, Icon Water, Canberra.

Icon Water Limited 2016b, Annual Report to the ACT Government 2015-16, Icon Water, Canberra.

Kanakoudis, V. \& Tsitsifli, S. 2010, 'Results of an urban water distribution network performance evaluation attempt in Greece', Urban Water Journal, vol. 7, no. 5, pp. 267-285.

Kim, E. \& Lee, H. 1998, 'Spatial integration of urban water services and economies of scale', Review of Urban and Regional Development Studies, vol. 10 no. 1, pp. 1-18.

Kirkpatrick, C., Parker, D. \& Zhang, Y.-F. 2006, 'An empirical analysis of state and private-sector provision of water services in Africa', The World Bank Economic Review, vol. 20, no. 1, pp. 143-163.

KPMG 2015, NPR Cost Benchmarking Study: A benchmarking study of the operating and capital costs of SA Water in support of a regulatory business proposal, RBP2106, using NPR 2014 data, SA Water, Adelaide.

Lambert, A. \& Taylor, R. 2010, Water Loss Guidelines, Water New Zealand, Wellington.

Lambert, D.K., Dichev, D. \& Raffiee, K. 1993, 'Ownership and sources of inefficiency in the provision of water services', Water Resources Research, vol. 29, no. 6, pp. 1573-1578.

Lynk, E. 1993, 'Privatisation, joint production and the comparative efficiencies of private and public ownership: the UK water industry case', Fiscal Studies, vol. 14, no. 2, pp. 98-116.

Marques, R.C. \& Monteiro, A.J. 2001, 'Application of performance indicators in water utilities management - a case-study in Portugal', Water science and technology, vol. 44, no. 2-3, pp. 95-102.

Martins, R., Fortunato, A. \& Coelho, F. 2006, Cost Structure of the Portuguese Water Industry: a Cubic Cost Function Application, Estudos do GEMF Working Paper No 9, GEMF.

Matos, R., Cardoso, A., Ashley, R., Duarte, P., Molinari, A. \& Schulz, A. 2003, Performance Indicators for Wastewater Services, International Water Association, London.

McKenzie, R., Lambert, A., Kock, J. \& Mtshweni, W. 2002, Benchmarking of leakage for water suppliers in South Africa. User Guide for the BENCHLEAK Model, Soth African Water Research Commission, Pretoria.

Mizutani, F. \& Urakami, T. 2001, 'Identifying network density and scale economies for Japanese water supply organizations', Papers in Regional Science, vol. 80, no. 2, pp. 211-230.

Molinos-Senante, M., Mocholi-Arce, M. \& Sala-Garrido, R. 2016, 'Efficiency assessment of water and sewerage companies: A disagregated approach accounting for service quality', Water Resources Management, vol. 30, no. 12, pp. 4311-4328.

Mugisha, S. 2007, 'Performance assessment and monitoring of water infrastructure: an empirical case study of benchmarking in Uganda', Water Policy, vol. 9, no. 5, pp. 475-491.

Munisamy, S. 2009, 'Efficiency and ownership in water supply: Evidence from Malaysia', International Review of Business Research Papers, vol. 5, no. 6, pp. 148-260. 
National Research Council 2009, Model framework for assessment of state, performance, and management of Canada's core public infrastructure, National Research Committee, Ottawa.

Nauges, C. \& van den Berg, C. 2007 , How "natural" are natural monopolies in the water supply and sewerage sector? Case studies from developing and transition Economie, World Bank, Washington, DC.

Nelson, T., Kelley, S., Orton, F., \& Simshauser, P. (2010). 'Delayed Carbon Policy Certainty and Electricity Prices in Australia', Economic Papers, vol. 29 no. 4, 446-465.

Norman, M. \& Stoker, B. 1991, Data envelopment analysis: the assessment of performance, John Wiley \& Sons, Inc.

NSW Government 2016, 2014-2015 Water Supply and Sewerage NSW Benchmarking Report, Department of Primary Industries, Sydney.

Nürnberg, H. 2001, 'German National Report. Performance Assessment of Water Supply Systems', Proceedings of the IWA - World Water Congress, Berlin.

Office of the Water Services United Kingdon and Wales 2013, Key indicators - guidance OFWAT, London.

Picazo-Tadeo, A.J., González-Gómez, F. \& Sáez-Fernández, F.J. 2009, 'Accounting for operating environments in measuring water utilities' managerial efficiency', The Service Industries Journal, vol. 29, no. 6, pp. 761-773.

Picazo-Tadeo, A.J., Sáez-Fernández, F.J. \& Gonzalez-Gomez, F. 2009, 'The role of environmental factors in water utilities' technical efficiency. Empirical evidence from Spanish companies', Applied Economics, vol. 41, no. 5, pp. 615-628.

Picazo-Tadeo, A.J., Sáez-Fernández, F.J. \& González-Gómez, F. 2008, 'Does service quality matter in measuring the performance of water utilities?', Utilities Policy, vol. 16, no. 1, pp. 30-38.

Pointon, C. \& Matthews, K. 2016, 'Reprint of: Dynamic efficiency in the English and Welsh water and sewerage industry', Omega, vol. 60, pp. 98-108.

Power and Water Corporation 2011, Indigenous essential services drinking water quality summary Power and Water Corporation, Darwin.

Power and Water Corporation 2016, Annual Report 2015-2016, Power and Water Corporation, Darwin. Productivity Commission 2011, Australia's urban water sector. Volume 1, Report \# 55, Australian Government Canberra.

Raffiee, K., Narayanan, R., Harris, T. \& Collins, J. 1992, 'Cost analysis of water utilities: a goodness-offt approach', Atlantic Economic Journal, vol. 21, no. 3, pp. 21-29.

Qldwater 2015, Cost drivers for the Queensland local government water and sewerage service providers, Local Government Association of Queensland, Newstead. 
Queensland Government 2016, Queensland service provider performance comparative report. Financial year 2014-2015, Department of Eneregy and Water Supply, Brisbane.

Queensland Government 2017, 'List of Registered Water and Sewerage Supply Service Providers', Department of Energy and Water Supply. Retrieved 3 April 2017 from

https://www.dews.qld.gov.au/water/regulation/provider

Rathor, A., Sinha, S., Pendley, D., Harris, G., Brueck, T., Mitchell, T. \& Francisco, W. 2014, Utility benchmarking for drinking water. Synthesis report, Water Environment Research Foundation and International Water Association, Alexandria.

Renzetti, S. 1999, 'Municipal water supply and sewerage treatment: costs, prices and distortions', Canadian Journal of Economics, vol. 32, no. 3, pp. 689-704.

Renzetti, S. \& Dupont, D. 2009, 'Measuring the technical efficiency of municipal water suppliers: The role of environmental factors', Land Economics, vol. 85, no. 4, pp. 627-36.

Saal, D.S., Parker, D. \& Weyman-Jones, T. 2007, 'Determining the contribution of technical change, efficiency change and scale change to productivity growth in the privatized English and Welsh water and sewerage industry: 1985-2000', Journal of Productivity Analysis, vol. 28, no. 1-2, pp. 127-139.

Sauer, J. 2005, 'Economies of scale and firm size optimum in rural water supply', Water Resources Research, vol. 41, no. 11, p. doi:10.1029/2005WR004127.

Sauer, J. \& Frohberg, K. 2007, 'Allocative efficiency of rural water supply-a globally flexible SGM cost frontier', Journal of Productivity Analysis, vol. 27, no. 1, pp. 31-40.

Sawkins, J. 1996, 'Balancing multiple interest in regulation: an event study of the English and Welsh water industry', Journal of Regulatory Economics, vol. 9, no. 3, pp. 249-268.

Sawkins, J.W. \& Accam, B. 1994, Comparative efficiency measurement in the Scottish water industry: an application of data envelopment analysis, University of Aberdeen, Department of Economics.

Shaoul, J. 1997, 'A critical financial analysis of the performance of privatize industries: the case of the water industry in England and Wales', Critical Perspectives on Accounting, vol. 8, no. 5, pp. 479-505.

Singh, M.R., Mittal, A.K. \& Upadhyay, V. 2011, 'Benchmarking of North Indian urban water utilities', Benchmarking: An International Journal, vol. 18, no. 1, pp. 86-106.

State of Queensland 2014, Key performance indicators for Queensland urban water service providers, Department of Energy and Water Supply, Brisbane.

Thanassoulis, E. 2000, 'DEA and its use in the regulation of water companies', European Journal of Operational Research, vol. 127, no. 1, pp. 1-13.

Thanassoulis, E. 2002, 'Comparative performance measurement in regulation: the case of English and Welsh sewerage services', Journal of the Operational Research Society, vol. 53, no. 3, pp. 292-302. 
Theuretzbacher-Fritz, H., Schielein, J., Kiesl, H., Kölbl, J., Neunteufel, R. \& Perfler, R. 2005, 'Transnational water supply benchmarking: the cross-border co-operation of the Bavarian EFFWB project and the Austrian OVGW project', Water Science and Technology: Water Supply, vol. 5, no. 6, pp. 273-280.

Tupper, H.C. \& Resende, M. 2004, 'Efficiency and regulatory issues in the Brazilian water and sewage sector: An empirical study', Utilities Policy, vol. 12, no. 1, pp. 29-40.

van den Berg, C. \& Danilenko, A. 2011, The IBNET water supply and sanitation performance Blue Book : The International Benchmarking Network for Water and Sanitation Utilities Databook, World Bank, Washington, DC

Walter, M., Cullmann, A., von Hirschhausen, C., Wand, R. \& Zschille, M. 2009, 'Quo vadis efficiency analysis of water distribution? A comparative literature review', Utilities Policy, vol. 17, no. 3, pp. 225232.

Woodbury, K. \& Dollery, B. 2004, 'Efficiency Measurement in Australian Local Government: The Case of New South Wales Municipal Water Services', Review of Policy Research, vol. 21, no. 5, pp. 615-636.

Worthington, A. 2011, 'Efficiency, technology and productivity change in Australian water utilities', Discussion Paper Series in Economics, No. 2011-08, Griffith University, Brisbane.

Worthington, A. 2014, 'Nonparametric models of technical efficiency in urban water utilities', in Economic and Financial Modelling of Markets, Institutions and Instruments, ed. A. Worthington, Nova Science Publishers, New York, pp. 217-234.

Zschille, M. 2015, 'Consolidating the water industry: An analysis of the potential gains from horizontal integration in a conditional efficiency framework', Journal of Productivity Analysis, vol. 44, no. 1, pp. 97114. 